Portland State University

PDXScholar

7-29-1975

\title{
Effects of Antifibroblast Antiserum on Cells Derived from Fibroblast Outgrowth of Human Prostatic Tissues
}

Eva Shang-Lian King

Portland State University

Follow this and additional works at: https://pdxscholar.library.pdx.edu/open_access_etds

Part of the Biology Commons

Let us know how access to this document benefits you.

Recommended Citation

King, Eva Shang-Lian, "Effects of Antifibroblast Antiserum on Cells Derived from Fibroblast Outgrowth of Human Prostatic Tissues" (1975). Dissertations and Theses. Paper 2380.

https://doi.org/10.15760/etd.2377

This Thesis is brought to you for free and open access. It has been accepted for inclusion in Dissertations and Theses by an authorized administrator of PDXScholar. Please contact us if we can make this document more accessible: pdxscholar@pdx.edu. 
AN ABSTRACT OF THE THESIS OF Eva Shang-Lian King for the Master of Science presented 29 July 1975.

Title: Effects of Antifibroblast Antiserum on Cells

Derived from Fibroblast Outgrowth of Human

Prostatic Tissues

APPROVED BY MEMBERS OF THE THESIS COMMITTEE:

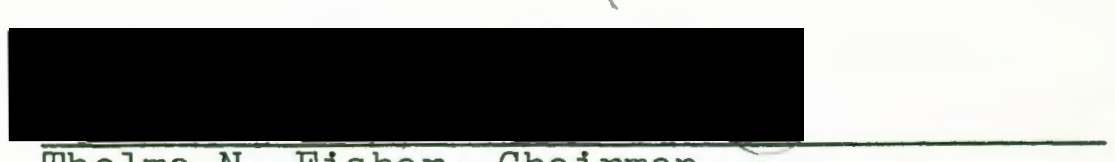

Thelma N. Fisher, Chairman

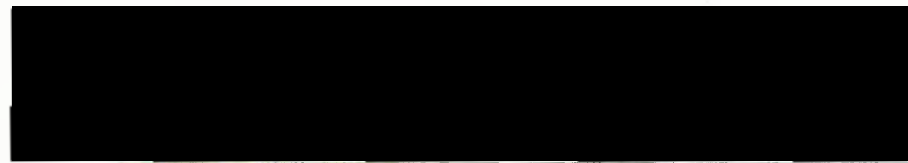

Earl Fisher, Jr.

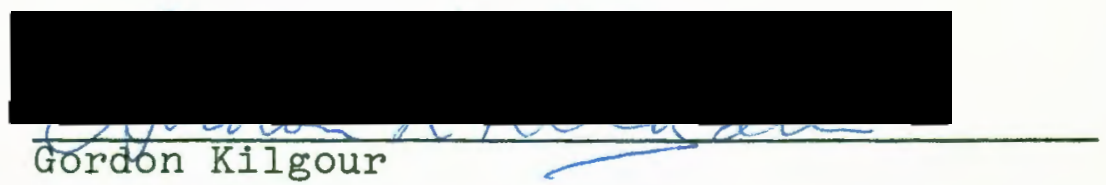

The purpose of this investigation was to provide pure cultures of normal human prostatic epithelium free of fibroblasts in order to study malignant conversion by chemical carcinogens. Normal epithelial cells were needed because this was the cell type implicated in prostatic malignancies of human subjects. Unfortunately fibroblasts grew faster than epithellal cells so that cultures were always overgrown with connective tissue elements. It was considered important to find a method which would eliminate fibroblasts so that normal epithelial cells could grow out in pure culture. 
Fibroblast cultures were obtained from human prostatic tissues fed with Eagle's medium contalning 20\% fetal bovine serum. To prepare antifibroblast antiserum rabbits were injected intravenously with human prostatic fibroblasts which had been transferred through at least 14 tissue culture passages. Complement flxation tests were used successfully to measure reactions of rabbit antifibroblast antiserum with prostatic fibroblasts. It was shown that in the rabbit antifibroblast antiserum reaction with complement and specific antigen, flbroblasts were lysed while prostatic epithelium was unaffected in mixed cell type cultures obtained from explant outgrowth of prostatic tissues. Control tissue cultures treated with normal rabbit serum remained unarfected when rabbit antifibroblast antiserum diluted $1: 2$ and complement diluted 1:5 were added to test systems.

Ammonium sulfate precipitation followed by DEAE cellulose column chromatography was used to isolate IgG from rabbit antifibroblast antiserum and normal rabbit serum. Only IgG purified from rabbit antifibroblast antiserum and added in the presence of complement had the ability to destroy fibroblasts and not epithelial cells. IgG obtained from normal rabbit serum had no effect.

When rabbit antifibroblast antiserum absorbed with $H$. Ep. 2 cells and complement were added to cultures of mixed cell types obtained from cellular outgrowth of human prostatic explants similar results were achieved: cells exhibiting fibroblast-like morphology were destroyed while 
epithelial cells persisted and continued to multiply.

Thus fibroblasts were lyzed after treatment with

rabbit antifibroblast antiserum and complement. Epithelial cells remalned and proliferated in pure culture therby providing a model tissue culture system of normal human prostatic eplthelfum which was avallable for group studies designed to measure initial events in malignant conversion processes of prostatic tissue. 
EFFECTS OF ANTIFIBROBLAST ANTISERUM ON CELLS

DERIVED FROM FIBROBLAST OUTGROWTH OF

HUMAN PROSTATIS TISSUES

by

EVA SHANG-LIAN KING

A thesis submitted in partial fulfillment of the requirements for the degree of

MASTER OF SCIENCE

in

BIOLOGY

Portland State University

1975 
TO THE OFFICE OF GRADUATE STUDIES AND RESEARCH:

The members of the Committee approve the thesis of Eva Shang-Lian King presented 29 July 1975.

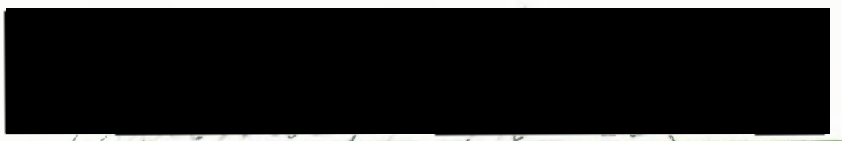

Thelma N. Fisher, Chairman
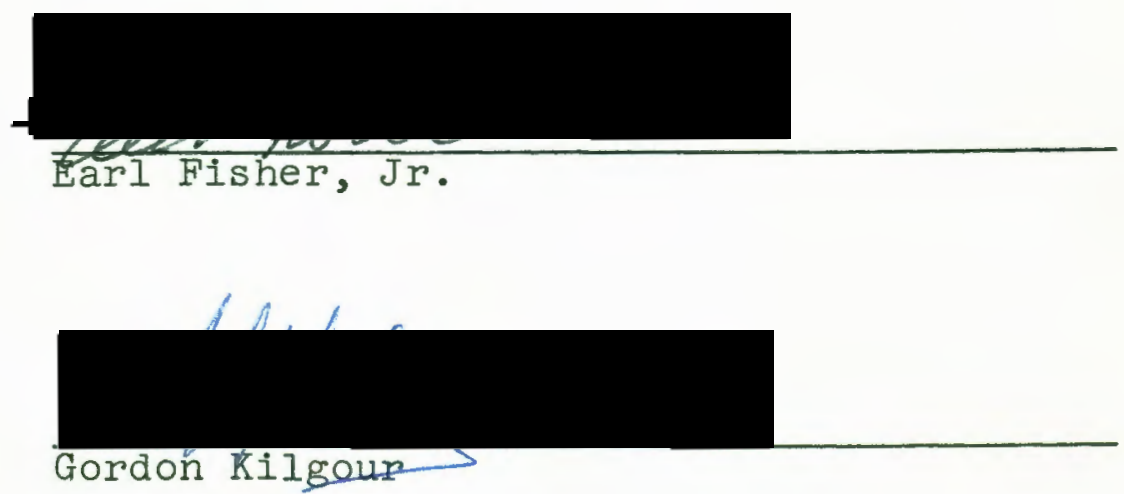

APPROVED :

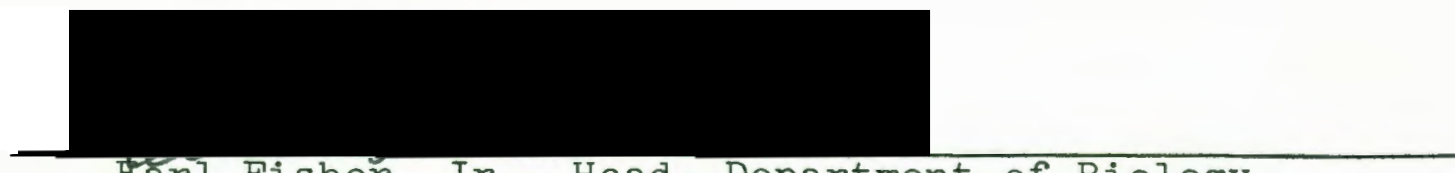

Earl Fisher, Jr., Head, Department of Biology

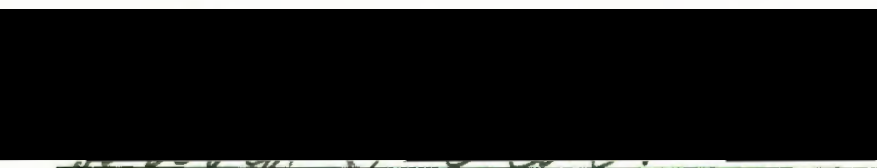

David T. Clark, Dean of Graduate Studies and Research 


\section{ACKNOWLEDGEMENTS}

Give thanks to God for blessing me here. I am grateful to my family for letting me have a chance to study here. I am really thankful for the instruction of my advisor, Dr. Thelma N. Fisher and committee members Drs. Earl Fisher, Jr. and Gordon Kilgour. I greatly appreciate Mrs. Donna Ann Fisher for her instruction in tissue culture maintenance techniques. 
ACKNOWLEDGEMENTS........................... 111

LIST OF TABLES.............................. v11

LIST OF FIGURES......................... Ix

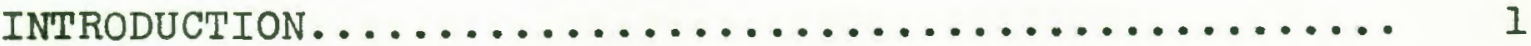

MATERIALS AND METHODS.......................... 3

Cell Cultures........................... 3

Procedures for Isolation, Feeding and Harvesting

Cell Cultures and the Media Used............ 3

Procedures for Rabbit Inoculation and Serum

Harvest............................ 6

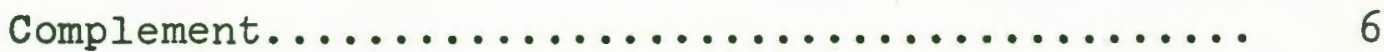

Complement Fixation Tests Employing Rabbit

Antifibroblast Antiserum and Fibroblast

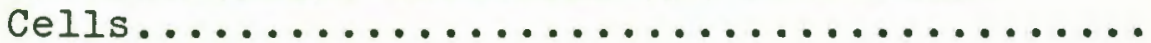

Indicator system....................

Test System......................

Procedure for Measuring the Effect of Non-Heat-

Inactivated Rabbit Antifibroblast Antiserum

on Fibroblasts and H. Ep. 2 Cells...........

Determination of the Most Effective Concentration of Heat Inactivated Rabbit. Antifibroblast

Antiserum and Complement Necessary to Lyse Fibroblasts Observed in Mixed Fibroblast and Epithelial Cellular Outgrowth from Human

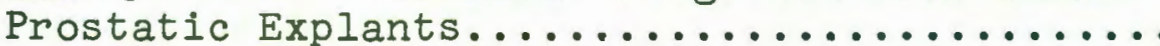

Purification of IgG Obtained from Normal Rabbit

Serum and Rabbit Antifibroblast Antiserum.....

Ammonium Sulfate Precipitation (2)........ 10

DEAE Cellulose Column Chromatography (2).... 12

Complement Fixation Tests Using IgG Obtained from Rabbit Antifibroblast Antiserum and Fibroblast

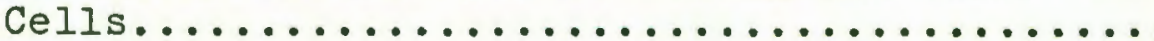


PAGE

Indicator system....................... 14

Test System............................. 14

A Comparison of Activies of IgG Obtained from Normal Rabbit Serum and from Rabbit Antifibroblast Antiserum on Human Prostatic Cultures Consisting of Mixed Fibroblast and Epithelial

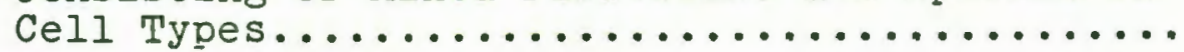

An Attempt to Remove Antibodies of Epithelial Cells from Non-Heat-Inactivated Rabbit Antifibroblast Antiserum by Treating

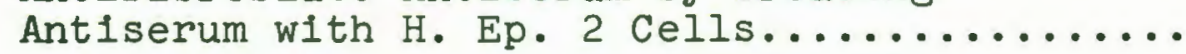

Complement Fixation Tests with Rabbit Antifibroblast Antiserum and Fibroblast Cell Cultures Derived from Human Prostatic

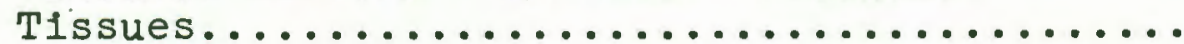

Visual Effects of Non-Heat-Inactivated Rabbit Antifibroblast Antiserum on Fibroblasts and H. Ep. 2 Cells.......................

Determination of Effective Concentrations of Heat Inactivated Rabbit Antifibroblast Ant1serum and Complement as Used to Lyse Fibroblasts Present in Cultures of Mixed Cell Types Derived from Human Prostatic Explants...

Purification of IgG Recovered from Rabbit Antifibroblast Antiserum and Normal Rabbit

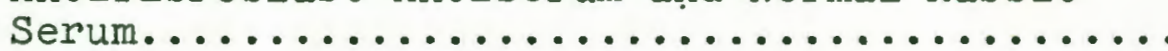

Purification of Gamma Globulin Isolated from Rabbit Ant1fibroblast Antiserum by DEAE Cellulose Column Chromatography...........

Analytical Ultracentrifugation Information Used to Characterize Gamma Globulin Isolated from Rabbit Antifibroblast Antiserum by DEAE Cellulose Column Chromatography............

Purification of Gamma Globulin Isolated from Normal Rabbit Serum by DEAE Cellulose Column

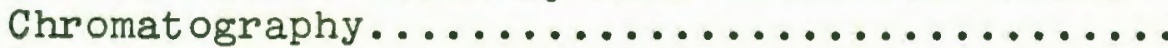


Analytical Ultracentrifugation Data Used to Characterize Gamma Globulin Isolated from Normal Rabbit Serum by DEAE Cellulose

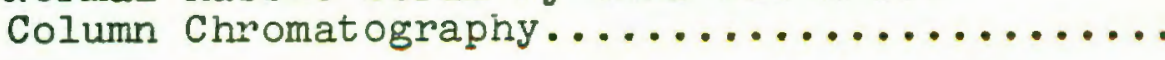

Complement Fixation Tests Using IgG Isolated from Rabbit Antifibroblast Antiserum as Antibody and Human Prostatic Fibroblasts

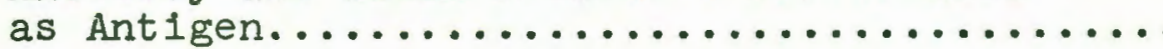

Indicator system................... 53

Test System......................... 54

Effects of IgG Obtained from Rabbit Antifibroblast Antiserum and Normal Rabbit Serum on mixed Human Prostatic Cultures Composed of

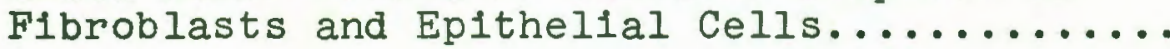

Effects of Non-Heat Inactivated Rabbit Antifibroblast Antiserum Absorbed with H. Ep. 2 Cells on Human Prostatic Cultures Composed of Fibro-

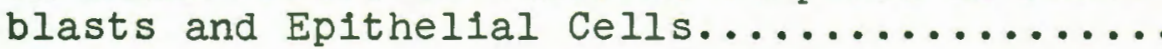

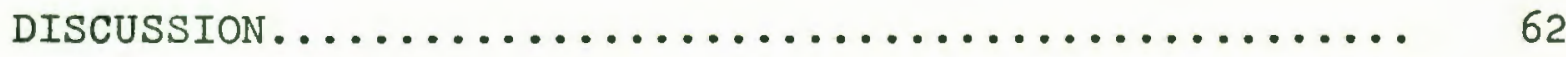

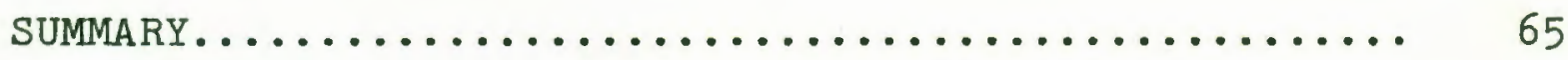

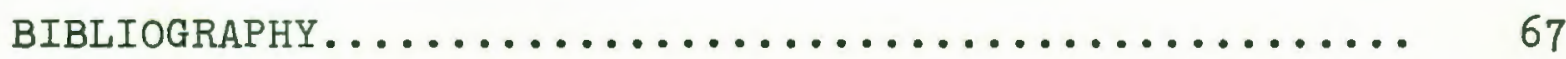




\section{LIST OF TABLES}

TABLE

PAGE

I Formula of Hanks' Balanced Salt Solution,

(10X) stock Solution.................... 4

II Constituents of a Modified Eagle's Medium as

Used to Cultivate Human Prostatic Tissues....

II Lowry (Folin-Ciocalteau) Method for Protein

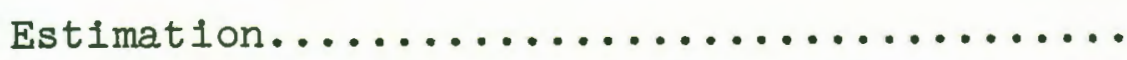

IV An Estimation of the Amount of Rabbit Anti-

fibroblast Antiserum required to fix

Complement in the Presence of Varying

Dilutions of Fibroblast Cell Suspensions..... I8

$V$ Results of Control Systems and Different

Dilutions of Rabbit Antifibroblast

Antiserum with Complement on Cultures

Composed of Mixed Fibroblasts and

Epithelial Cells Derived from Human

Prostatic Tissues...................... 23

VI Data Required for the Calculation of the

Sedimentation Coefficient of IgG Isolated

from Rabb1t Antifibroblast Antiserum.......

47

VII Data Required for the Calculation of the Sedimentation Coefficient of IgG Isolated

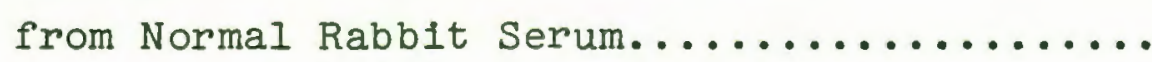


VIII A Complement Fixation Reaction with IgG

Isolated from Rabbit Artifibroblast

Antiserum and Suspensions of Human

Prostatic Fibrobiasts Serving as Test

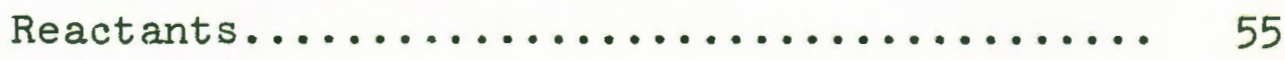


A comparison of fibroblast and H. Ep. 2

cell cultures before and after treatment

with antifibroblast antiserum and

complement....................... 20

Photographic demonstration of selective

effects of antifibroblast antiserum and

complement on cultures of mixed cell types

arising from explants of human prostatic

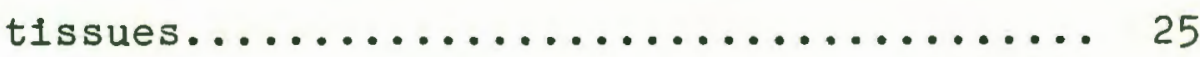

3 Standard curve as prepared by the Lowry

method for protein estimation and used to calculate protein content of rabbit antifibroblast antiserum and that of fractions derived from it................... 42

4 Standard curve as prepared by the Lowry

method for protein estimation and used to calculate protein content of normal rabbit serum and that of fractions derived from $1 t \ldots \ldots \ldots \ldots \ldots \ldots \ldots \ldots \ldots . \ldots \ldots$

5 Tracing of a partially purified peak of gamma globulin 1solated from rabbit ant1fibroblast antiserum by DEAE cellulose column chromatography................ 45 
Plot of $\log _{10} x$ versus $t$ as used for the calculation of a sedimentation coefficient for gamma globulin (IgG) isolated from antifibroblast antiserum............ 48

7 Tracing of a partially purified peak of gamma globulin isolated from normal rabbit serum by DEAE cellulose column chromatography........................... 50

8 Plot of $\log _{10} x$ versus $t$ as used for the calculation of a sedimentation coefficient for gamma globulin ( $I g G$ ) isolated from normal rabbit serum................ 52 9 Observation of lytic effects by purified IgG isolated from rabbit antifibroblast antiserum on fibroblasts derived from human prostatic explant outgrowth composed of fibroblasts and ep1thelial

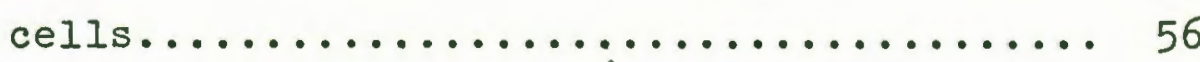

10 Effect of complement and non-heatInactivated, H. Ep. 2-cell absorbed, rabbit antifibroblast antiserum on cellular outgrowth of mixed cell types obtained from human prostatic explant tissue...... 60 
Fibroblasts derived from human fetal tissue (21, 27, 15), human skin $(8,25)$, chick embryo (26), and murine embryo (12), etc., have been studied extensively by others in order to determine hexosaminidase activity (10), to assess the effects of $\mathrm{pH}$ (8) and amino acid composition (15) on growth, to measure dihydrotestosterone formation (25), to study adhesion properties $(16,17)$, and to 1solate glycoproteins from cell surfaces (26). Fibroblasts derlved from numerous human prostatic tissues were tested in our study. For the preparation of antiserum many investigators Immunized rabbits via the intravenous route $(18,24)$, by intramuscular and intravenous injections (7, 15), by intradermal inoculation (22, 9, 18), by alternating intraperitoneal with subcutaneous type infections (5), or by foot pad inoculations $(4,6)$. Intravenous procedures via marginal ear veins of rabbits provided a satisfactory method for preparing antifibroblast antiserum used in our research.

Because it was necessary to prepare pure cultures of normal prostatic epithelium free of fibroblasts in order to study malignant conversion by chemical carcinogens an effective method to eljminate fibroblast outgrowth from prostatic explants was required. Recovery of epithellum was essential since this cell type was thought to undergo malignant transformation in human subjects. Fibroblasts multiplied more rapidly than epithelial cells thereby overgrowing eplthelial cultures. Our purpose was to destroy 
fibroblasts so that normal epithelial cells would proliferate freely in pure culture. Subsequently, a cancer research group hoped to study initial events in the malignant conversion process by treating known normal human prostatic epithelial cells with chemical carcinogens. It was obvious to all investigators involved in this field of research that the first enormous problem was to control overgrowth of epithelium by fibroblasts. To make antifibroblast antiserum in rabbits via intravenous inoculation and to test the effects of antibody in the presence of complement on fibroblasts derived from human prostatic tissue, was the purpose of this study. We hoped to demonstrate that such a system destroyed cells which resembled fibroblasts, thereby allowing typical epithelial cell types to persist and flourish. 
MATERIALS AND METHODS

Ce11 Cultures

F1broblast cultures were isolated from human prostatic tissues removed surgically from patients at Providence Hospital, Portland, Oregon. H. Ep. 2 cells, human epithelium obtained originally from a patient with carcinoma of the larynx, were carried in continuous culture in our laboratory through 280 transfers. Often mixed cultures of flbroblast and epithellal cell types were obtained from prostatic explant outgrowth. These cultures were subjected to antifibroblast antiserum treatment also.

\section{Procedures for Isolation, Feeding and Harvesting Cell}

Cultures and the Media Used

Hanks' Balanced Salt Solution containing antibioties (penicilin and streptomycin) was used to wash prostatic tissues 3 times. Tissues were cut into small $2 \mathrm{~mm}^{2}$ pieces when held in the third wash solution. Explants were placed in small plastic petri dishes $(60 \times 15 \mathrm{~mm})$ and allowed to remain at room temperature for approximately $1 \mathrm{hr}$, after which time Eagle's medium contalning $30 \%$ fetal bovine serum (Flow Laboratories) was added. Cultures were held in a 95\% a1r-5\% $\mathrm{CO}_{2}$ water-saturated environment at $37^{\circ}$. Hanks' Balanced Salt Solution and Eagle's medlum as in Table I and Table II respectively were prepared as indicated in the formulae.

Fibroblast cultures were fed $3-5$ times per week with 
FORMULA OF HANKS' BALANCED SALT SOLUTION, (IOX) STOCK SOLUTION

\section{Materials}

Solution A

$\mathrm{NaCl}$

$\mathrm{KCl}$

$\mathrm{MgSO}_{4} \cdot 7 \mathrm{H}_{2} \mathrm{O}$

The above reagents were dissolved in about $300 \mathrm{ml}$ distilled water.

Solution B
$\mathrm{KH}_{2} \mathrm{PO}_{4}$
$0.6 \mathrm{gms}$
$\mathrm{Na}_{2} \mathrm{HPO}_{4} \cdot 2 \mathrm{H}_{2} \mathrm{O}$
$0.6 \mathrm{gms}$
Glucose
$10 \mathrm{gms}$

These compounds were dissolved in approximately $300 \mathrm{ml}$ distilled water.

Solution C

$\mathrm{CaCl}_{2}$ $1.4 \mathrm{gms}$

Calcium chloride was dissolved in $200 \mathrm{ml}$ distilled water and added to Solutions $A$ and $B$.

Solution D

Phenol Red $0.2 \%, 100 \mathrm{ml}$

The final volume was brought to $1,000 \mathrm{ml}$ and the solution was sterilized by Sietz filtration. Ten times concentrated Hanks' solution was stored at $4^{\circ}$ until dilute Hanks' preparation was required. 
TABLE II

CONSTITUENTS OF A MODIFIED EAGLE'S MEDIUM AS

USED TO CULTIVATE HUMAN PROSTATIC TISSUES

Materials

Hanks' Balanced Salt Solution

Fetal Bovine Serum

(Inactivated at $56^{\circ}$ for $30 \mathrm{~min}$ )

Non Essential Amino Acids (100x, Flow

Laboratories)

Vitamins (100x, Flow Laboratories)

Amino Aclas (100x, Flow Laboratories)

Penicillin [Stock Solution: 20,000 units

per ml (Pfizer Laboratories)]

Streptomycin [Stock Solution: $20 \mathrm{mg}$ per

ml (Pfizer Laboratories)]

$5 \% \mathrm{NaHCO}_{3}$

Putrescine ( $1 \mathrm{mg} / \mathrm{ml}$, Sigma Laboratories)

Glutamine (100x, Flow Laboratories)
Amount

$85 \mathrm{ml}$

$20 \mathrm{ml}$ or $30 \mathrm{ml}$
$1 \mathrm{ml}$

$1 \mathrm{ml}$

$1 \mathrm{ml}$

$1 \mathrm{ml}$

$1 \mathrm{ml}$

$2 \mathrm{ml}$

$0.25 \mathrm{ml}$

$1 \mathrm{ml}$ 
Eagle's medium containing 20\% fetą bovine serum. Trypsin $(0.25 \%$, Difco) was used to subculture fibroblasts. Tissues were cultivated in $30 \mathrm{ml}$ plastic tissue culture flasks or in $200 \mathrm{ml} \mathrm{milk} \mathrm{dilution} \mathrm{bottles.}$

Human prostatic fibroblasts were subcultured for at least 14 passages before they were used experimentally. Cells (approximately $2.35 \times 10^{6}$ per $\mathrm{ml}$ ) were washed twice with 10 ml each of saline, and harvested in a small amount of saline. These cells were frozen and thawed 3 times then inactivated in a water bath at $56^{\circ}$ for $30 \mathrm{~min}$. This crude preparation served as antigen which was used to Immunize rabbits.

Procedures for Rabbit Inoculation and Serum Harvest

The prepared antigen ( $0.1 \mathrm{ml}$ per inoculation) was injected intravenousiy into ear marginal veins of rabbits, 3 times per week for 3 weeks. A booster inoculation was given one week later. After a few days, rabbits were bled from the heart in order to obtain $15 \mathrm{ml}$ blood from each animal. Rabbit blood was refrigerated overnight at $4^{\circ}$ in a centrifuge tube. Clots were rimmed carefully $24 \mathrm{hr}$. later and blood was centrifuged twice in order to obtain large serum ylelds free of red blood cells. Serum was inactivated at $56^{\circ}$ for $30 \mathrm{~min}$.

\section{Complement}

The complement employed throughout consisted of lyophilized guinea pig serum obtained commerclally (Flow 
Laboratories). Just before use complement was dissolved, in the cold, in $7 \mathrm{ml}$ diluent of which the latter contalned $6 \%$ sodium acetate and $2 \%$ borlc acid.

Complement Fixation Tests Employing Rabbit Antifibroblast Antiserum and Fibroblast Cells

Indicator system. The titration of hemolysin as described by Burrell (1) was achieved by using $0.5 \mathrm{ml}$ hemolysin dilutions ranging from $1: 1,000$ to $1: 16,000$ with $0.3 \mathrm{ml}$ of a solution made up of complement diluted $1: 30,0.5 \mathrm{ml}$ of a $2 \%$ suspension of sheep erythrocytes and $1.7 \mathrm{ml}$ of $0.01 \mathrm{mg} \% \mathrm{MgSO}_{4}$ dissolved in physiological saline (Mag saline).

According to Burrell (1) complement was titrated using the following components: two units of an adequate dilution of hemolysin contained in $0.5 \mathrm{ml}, 0.1$ to $0.5 \mathrm{ml}$ of a fresh solution made up of complement diluted $1: 30,0.5 \mathrm{ml}$ of a $2 \%$ suspension of sheep erythrocytes and Mag saline added to provide a final volume of $2.5 \mathrm{ml}$ per tube were included in the titration.

Test System. It was considered necessary to determine adequate concentrations of antigen and antibody required to observe lysis of fibroblasts. A master titration of fibroblasts was achieved by first preparing 2 doubling dilutions starting with a $1: 5$ dilution of suspended fibroblasts. Rabbit antifibroblast antiserum, heat inactivated $30 \mathrm{~min}$ at $56^{\circ}$, was diluted $1: 5$ and $1: 20$. Four rows of $13 \times 100 \mathrm{~mm}$ test 
tubes were arranged so that there were 3 tubes per row. Inocula were plpetted as follows: tube 1 of each row---0.5 $\mathrm{ml}$ of 1:5 inoculum, tube 2 of each row---0.5 ml of 1:10 inoculum, tube 3 of each row-- $-0.5 \mathrm{ml}$ of $1: 20$ inoculum. Rabbit antifibroblast antiserum was pipetted as follows: two-tenths $\mathrm{ml}$ of undilute serum was added to each tube in the first row; $0.2 \mathrm{ml}$ of serum diluted $1: 5$ was added to each tube in the second row; $0.2 \mathrm{ml}$ of serum diluted $1: 10$ was added to each tube in the third row and $0.2 \mathrm{ml}$ of serum was diluted $1: 20$ and added to each tube in the fourth row. The following controls were included: rabbit antifibroblast antiserum control ( $0.2 \mathrm{ml}$ of undiluted serum and $0.5 \mathrm{ml}$ of $\mathrm{Mag}$ saline), fibroblast antigen control $(0.5 \mathrm{ml}$ of fibroblasts diluted $1: 5$ and $0.2 \mathrm{ml}$ of Mag saline), and a hemolytic system control $(0.7 \mathrm{ml}$ of Mag saline). Preparations were incubated $15 \mathrm{~min}$ at room temperature, one $\mathrm{ml}$ of complement ( 2 units per $\mathrm{ml}$ ) was added to each tube. Preparations were held in the refrigerator for $15-18 \mathrm{hr}$. Tubes were placed in a $37^{\circ}$ water bath for $10 \mathrm{~min}$ after which time $0.5 \mathrm{ml}$ of hemolysin (2 units) and $0.5 \mathrm{mI}$ of a $2 \%$ suspension of sheep erythrocytes were added to each tube. A sheep erythrocytes control contalning $0.5 \mathrm{ml}$ of sheep red blood cells suspended in $2.2 \mathrm{ml}$ of Mag saline was included in each titration. Contents of each tube were mixed well and preparations were incubated at $37^{\circ}$ for $30 \mathrm{~min}$. 
Procedure for Measuring the Effect of Non-Heat-Inactivated Rabbit Antifibroblast Antiserum on Fibroblasts and H. Ep. 2 Cells

Initially growth fluids of fibroblast and H. Ep. 2 cell cultures were removed and appropriate photographs were made. Following photography cultures were fed with Eagle's medium containing $20 \%$ fetal bovine serum. To these preparations 0.1 $\mathrm{ml}$ of undiluted complement, and $0.1 \mathrm{ml}$ of undiluted rabbit antifibroblast antiserum were added to fibroblast and H. Ep. 2 cell cultures. Treated cultures were incubated in a 95\% air-5\% $\mathrm{CO}_{2}$ water-saturated environment at $37^{\circ}$. The next day cultures were examined for evidence of cell lysis and photographs were made to record the results.

Determination of the Most Effective Concentration of Heat Inactivated Rabbit Antifibroblast Antiserum and Complement Necessary to Lyse Fibroblasts Observed in Mixed Fibroblast and Epithelial Cellular Outgrowth from Human Prostatic Explants

Growth fluids were removed and cultures were photographed initially. Then cultures were fed with Eagle's medium containing $20 \%$ fetal bovine serum. Undluted rabbit antifibroblast antiserum $(0.2 \mathrm{ml})$ was added to cultures displaying mixed cell type (fibroblasts and epithelial cells) outgrowth. Other cultures showing outgrowth of mixed cell types were treated with a $0.2 \mathrm{ml}$ rabbit antifibroblast antiserum diluted $1: 2$. Test cultures were held in a $95 \%$ air $-5 \%$ 
$\mathrm{CO}_{2}$ water-saturated envirorment at $37^{\circ}$ for $15 \mathrm{~min}$, after which time $1 \mathrm{ml}$ of different dilutions of complement (undiluted, $1: 5,1: 10,1: 20,1: 30,1: 45 ; 1: 60,1: 75,1: 150)$ was added to appropriate cultures. Controls consisted of untreated cultures, cultures treated with $0.2 \mathrm{ml}$ undiluted rabbit antifibroblast antiserum, cultures treated with I $\mathrm{mI}$ complement diluted 1:20, cultures treated with $0.2 \mathrm{ml}$ undiluted heat inactivated normal rabbit serum and cultures treated with $1 \mathrm{ml}$ of complement diluted 1:5. Control and test systems were incubated in a $95 \%$ air-5\% $\mathrm{CO}_{2}$ water-saturated environmentat $37^{\circ}$ overnight then examined and photographed the following day.

Purification of IgG Obtained from Normal Rabbit Serum and Rabbit Antifibroblast Antiserum

Twenty-two $\mathrm{ml}$ allquots of normal rabbit serum and rabbit antifibroblast antiserum were processed in order to obtain IgG fractions from each serum sample. The procedure followed for purification of IgG was as follows:

\section{Ammonium Sulfate Precipitation (2)}

1. Saturated $\left(\mathrm{NH}_{4}\right)_{2} \mathrm{SO}_{4}$ ( $(\mathrm{II} \mathrm{ml}$ ) was adjusted to approximately $\mathrm{pH} 7.8$ by the addition of $2 \mathrm{~N} \mathrm{NaOH}$. This adjustment was made just prior to precipitation of gamma globulin in order to prevent ammonia release.

2. With constant stirring the $11 \mathrm{ml}$ of saturated $\left(\mathrm{NH}_{4}\right)_{2} \mathrm{SO}_{4}$ solution, $\mathrm{pH} 7.8$, was added slowly, in dropwise 
fashion to $22 \mathrm{ml}$ of serum. This procedure salted out those components which were insoluble in a $33.3 \%\left(\mathrm{NH}_{4}\right)_{2} \mathrm{SO}_{4}$ solution.

3. Upon completion of $\left(\mathrm{NH}_{4}\right)_{2} \mathrm{SO}_{4}$ addition, suspensions were stirred for 2 to $3 \mathrm{hr}$.

4. Subsequently, suspensions were centrifuged at room temperature for $30 \mathrm{~min}$ at $1,465 \mathrm{xg}$.

5. Precipitates were dissolved in enough saline to restore volumes of solutions to those of original serum samples.

6. Gamma globulin fractions were purified by a second and a third precipitation. For the second precipitation steps 1 through 5 were repeated. For the third precipitatIon, steps 1 through 4 were followed.

7. Precipitates from third precipitations were dissolved in borate-buffered saline to a final volume half that, or less than that of original serum samples.

8. Ammonium sulfate was removed from precipitates by dialyzing against borate-buffered saline for several days at $4^{\circ}$. Dialyzates were changed mornings and evenings, and at these intervals a few drops of $5 \% \mathrm{BaCl}_{2}$ and $3.7 \% \mathrm{HCl}$ were used to check for sulfate lons.

9. After dialysis was completed, solutions were removed from dialysis tubing then centrifuged $35 \mathrm{~min} 9,750 \times \mathrm{g}$, at $4^{\circ}$.

10. The Lowry (Folin-Ciocalteu) method for protein 
estimation was followed by adding standard solutions, saline, sample, reagent $A$, and reagent $B$ in amounts and sequences as shown in Table III.

Absorbance of reaction mixtures were observed at $500 \mathrm{~nm}$ as measured against a dist1lled water blank. A standard curve was prepared and protein concentrations of samples were read directly from the calibration curve.

\section{DEAE Cellulose Column Chromatography (2)}

1. A DEAE cellulose column equilibrated in $0.01 \mathrm{M}$ phosphate buffer, pH 7.5 was prepared.

2. Crude gamma globulin fractions were dialyzed against $0.01 \mathrm{M}$ phosphate buffer, $\mathrm{pH} 7.5$, for $24 \mathrm{hr}$ at $4^{\circ}$.

3. Gamma globulin fractions were removed from dialysis bags, centrifuged for $25 \mathrm{~min}$ at $1,085 \mathrm{xg}$, and sediments were discarded.

4. Protein content of supernatant fluids was est1mated by the Lowry Method.

5. Nine ml samples of crude gamma globulin were fractionated by DEAE cellulose column chromatography.

6. Samples which displayed the highest protein content were pooled and lyophilized.

7. Dried protein powders were dissolved in adequate amounts of distilled water in order to bring the final protein concentration to $4-5 \mathrm{mg} / \mathrm{ml}$. Protein solutions were dialyzed against $0.01 \mathrm{M}$ phosphate buffer, $\mathrm{pH} 7.5$, for 2 days at $4^{\circ}$. 
TABLE III

LOWRY (FOLIN-CIOCALTEAU) METHOD FOR PROTEIN ESTIMATION

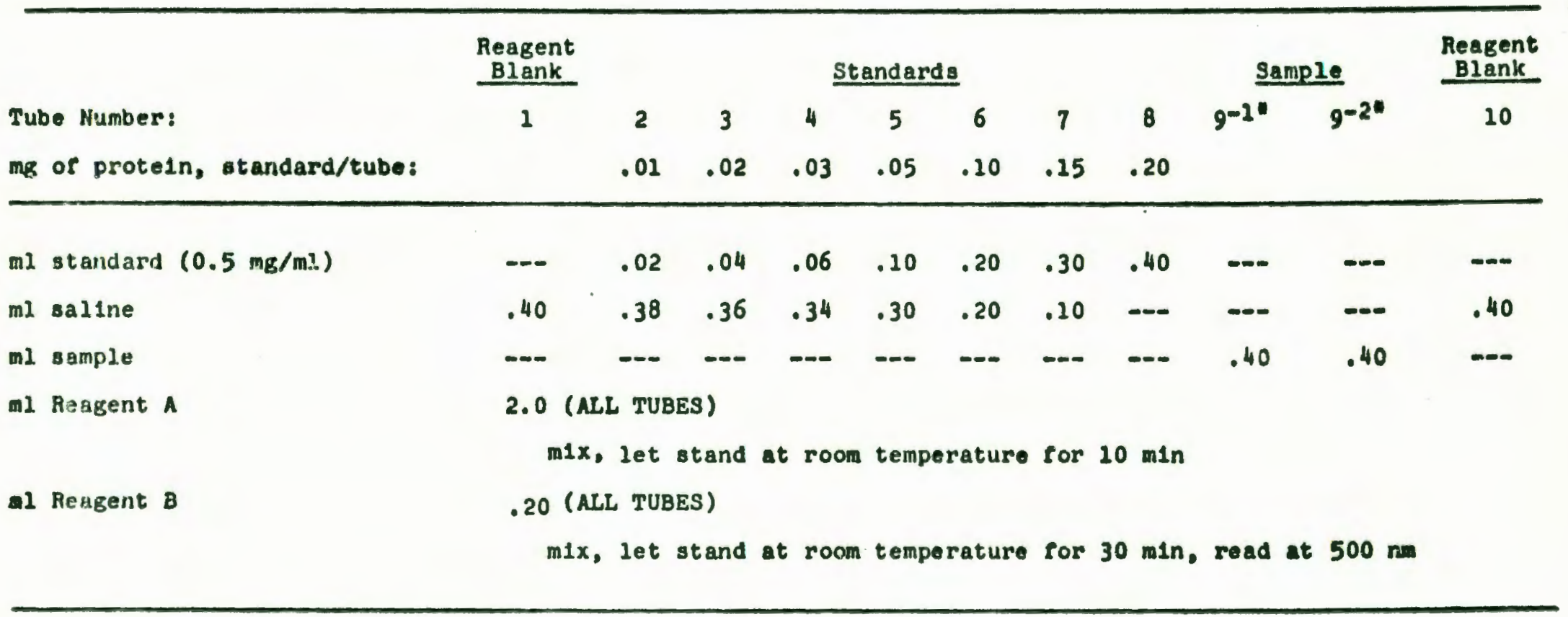

Reagent blanks, tandard dilutions and samples were tested in duplicate.

- Indicated that $0.1 \mathrm{ml}$ ample solution was diluted $1 \mathrm{n} 0.9 \mathrm{ml}$ saline $\left(9^{-1}\right)$ and $0.1 \mathrm{ml} 9^{-1} \mathrm{samplo}$ solution was diluted in $0.9 \mathrm{ml}$ saline $\left(9^{-2}\right)$. 
8. After completing dialysis procedures, solutions were centrifuged $25 \mathrm{~min}$ at $1,085 \times \mathrm{g}$. Sedimentation coefficients of protein solutions were determined following analytical centrifugation in a Model $E$ ultracentrifuge.

Complement Flxation Tests Using IgG Obtained from Rabbit Antifibroblast Antiserum and Fibroblast Cells

Indicator System. Methods for titrating hemolysin and complement ( 1 ) as described earlier were followed.

Test System. It was necessary to determine appropriate concentrations of reactants for this system. IgG obtained from rabbit antifibroblast antiserum was diluted 1:5 and $1: 10$ and added to suspensions of human prostatic fibroblasts diluted 1:5, and 1:10 in the presence of complement (2 units per $\mathrm{ml})$, as indicated earlier.

A Comparison of Activities of IgG Obtained from Normal Rabbit Serum and from Rabbit Antifibroblast Antiserum on Human Prostatic Cultures Consisting. of Mixed Fibroblast and Epithellal Cell Types

Growth fluids were removed and inftial photographs were made of all cell cultures. Cultures were fed with Eagle's medium containing $20 \%$ fetal bovine serum to which $0.2 \mathrm{ml}$ of undiluted IgG purffied from rabbit antifibroblast antiserum was added. Test systems were held in a 95\% air-5\% $\mathrm{CO}_{2}$ watersaturated environment at $37^{\circ}$ for $15 \mathrm{~min}$. One $\mathrm{ml}$ of 
complement diluted 1:5 was added to each culture. A control cell culture recelved $0.2 \mathrm{ml}$ undiluted IgG obtained from normal rabbit serum and $1 \mathrm{ml}$ of a solution made up of complement diluted 1:5. Preparations were examined and photographed.

An Attempt to Remove Antibodies of Epithelial Cells from NonHeat-Inactivated Rabbit Antifibroblast Antiserum by Treating Antiserum with $H . E p .2$ Cells

For absorption studies $2-200 \mathrm{ml}$ bottle cultures of $\mathrm{H}$. Ep. 2 cells approximately 5 days old were used for these experiments. Growth fluids were removed and $3.5 \mathrm{ml}$ rabbit antifibroblast antiserum were added to each culture. Cells were scraped from glass by means of rubber spatulas. Preparations were held $30 \mathrm{~min}$ in a $95 \%$ air-5\% $\mathrm{CO}_{2}$ water-saturated environment at $37^{\circ}$. Cells were centrifuged $15 \mathrm{~min}$ at $3,020 \mathrm{x} \mathrm{g}$. Supernatant fluids were retained while sedimented fractions were discarded. Presumably this supernatant fluid contained antifibroblast antiserum from which epithelial components of $H$. Ep. 2 cells had been removed by the absorption process. To test the effect of absorbed antifibroblast antiserum on cell cultures, growth fluids were removed from cultures of prostatic explants displaying mixed cell type outgrowth. Preparations were photographed then fed with Eagle's medium containing $20 \%$ fetal bovine serum and $0.2 \mathrm{ml}$ undiluted but absorbed antifibroblast antiserum. After $15 \mathrm{~min}$ incubation at $37^{\circ} 1 \mathrm{ml}$ of a solution made up of 
complement diluted $1: 5$ was added to preparations. Test systems were cultivated overnight in a $95 \%$ a1r-5\% $\mathrm{CO}_{2}$ watersaturated environment at $37^{\circ}$. The following day cultures were examined and photographed in order to document observed effects. 
Complement Fixation Tests with Rabbit Antifibroblast Ant1serum and Fibroblast Cell Cultures Derived from Human Prostatic Tissues

It was determined by titration that $0.5 \mathrm{ml}$ of a $1: 500$ dilution of hemolysin contained 2 units of complement. This amount proved to be the highest hemolysin dilution which gave complete sheep red blood cell hemolysis. Complement was titrated also. Two full units of a solution of complement diluted 1:75 and contained in $1 \mathrm{ml}$ was found to be the least amount of complement which provided complete lysis of sheep red blood cells.

The test system was carried out as described in Table IV.

When a 1:5 dilution of suspended fibroblast cells and a 1:10 dilution of rabbit antifibroblast antiserum were included in test systems, the greatest amount of complement fixation was observed. From such observations it was evident that antibody specific for fibroblasts was present in the rabbit antiserum.

Visual Effects of Non-Heat-Inactivated Rabbit Ant1fibroblast Ant1serum on Fibroblasts and H. Ep. 2 Cells

After treating human prostatic fibroblasts with rabbit antifibroblast antiserum in the presence of complement, growth of fibroblasts was limited and cell lysis occurred so that fibroblasts disappeared from cultures in 24 to $72 \mathrm{hr}$. 
AN ESTIMATION OF THE AMOUNT OF RABBIT ANTIFIBROBLAST ANTISERUM REQUIRED TO FIX COMPLEMENT IN THE PRESENCE OF VARYING DILUTIONS OF

FIBROBLAST CELL SUSPENSIONS

\begin{tabular}{|c|c|c|c|c|}
\hline Rabb1t Ant1fibroblast & Flbroblast & $\mathrm{Cell}$ & Suspension & Dilutions \\
\hline Ant1serum Dilutions & $1: 5$ & & $1: 10$ & $1: 20$ \\
\hline Undiluted & + & & + & + \\
\hline $1: 5$ & ++ & & + & + \\
\hline $1: 10$ & ++++ & & +++ & - \\
\hline $1: 20$ & ++ & & - & - \\
\hline
\end{tabular}

Symbols:

$+=$ no hemolysis

$-=$ hemolysis 
Rabbit antifibroblast antiserum and complement had no visible effect on H. Ep. 2 cells. The latter were known to be mal1gnant eplthelold cell types. These findings suggested that rabbit antifibroblast antiserum added in the presence of complement brought about a specific reaction with fibroblasts which caused them to lyse; however, such activity was not demonstrable for H. Ep. 2 cells. Photographs displaying these effects were documented and recorded in Figure 1.

Determination of Effective Concentrations of Heat Inactivated Rabbit Antifibroblast Antiserum and Complement as Used to Lyse Fibroblasts Present in Cultures of Mixed Cell Types Derived from Human Prostatic Explants

As seen in Table V, I ml of complement diluted $1: 5$ and $0.2 \mathrm{ml}$ of antifibroblast antiserum diluted $1: 2$ provided the best conditions for fibroblast cell lysis when these reagents were used. Antifibroblast antiserum represented pooled serum collected from 6 immunized rabbits as obtained early during these studies.

Depending on controls, rabbit antifibroblast antiserum alone or complement alone or normal raboit serum with complement gave negative results throughout. It was apparent that it was necessary to add complement in the reaction mixture in order to achleve lysis of fibroblasts when antigen reacted with antibody. Also, it appeared that rabbit antifibroblast antiserum was specific for cells demonstrating fibroblast like morphology but not for cells resembling epithelium. 
Figure 1. A comparison of fibroblast and H. Ep. 2 cell cultures before and after treatment with antifibroblast antiserum and complement.

Fibroblast cultures (12th passage) were obtalned Initially from human prostatic tissue while H. Ep. 2 cells (epithelial like) were 1solated originally from a patient known to have carcinoma of the larynx. Photographs, taken with a Zeiss Standard W. L. Research Microscope equipped with Polaroid attachments, were made just before treatment of cultures (Figs. la and lc) with antifibroblast antiserum $(0.1 \mathrm{ml}$ of undiluted preparation) and complement $(0.1 \mathrm{ml}$ of undiluted preparation). Twenty-five hours following treatment with antifibroblast antiserum plus complement, photographs were recorded again (Figs. $1 b$ and 1d). Photographs shown in Figs. $1 \mathrm{a}$ and $1 \mathrm{~b}$ were made of fibroblast cultures before and after antifibroblast treatment respectively while photographs displayed in Figs. Ic and $1 d$ were made of $\mathrm{H}$. Ep. 2 cells before and after antifibroblast treatment respectively. Magnification x205. 

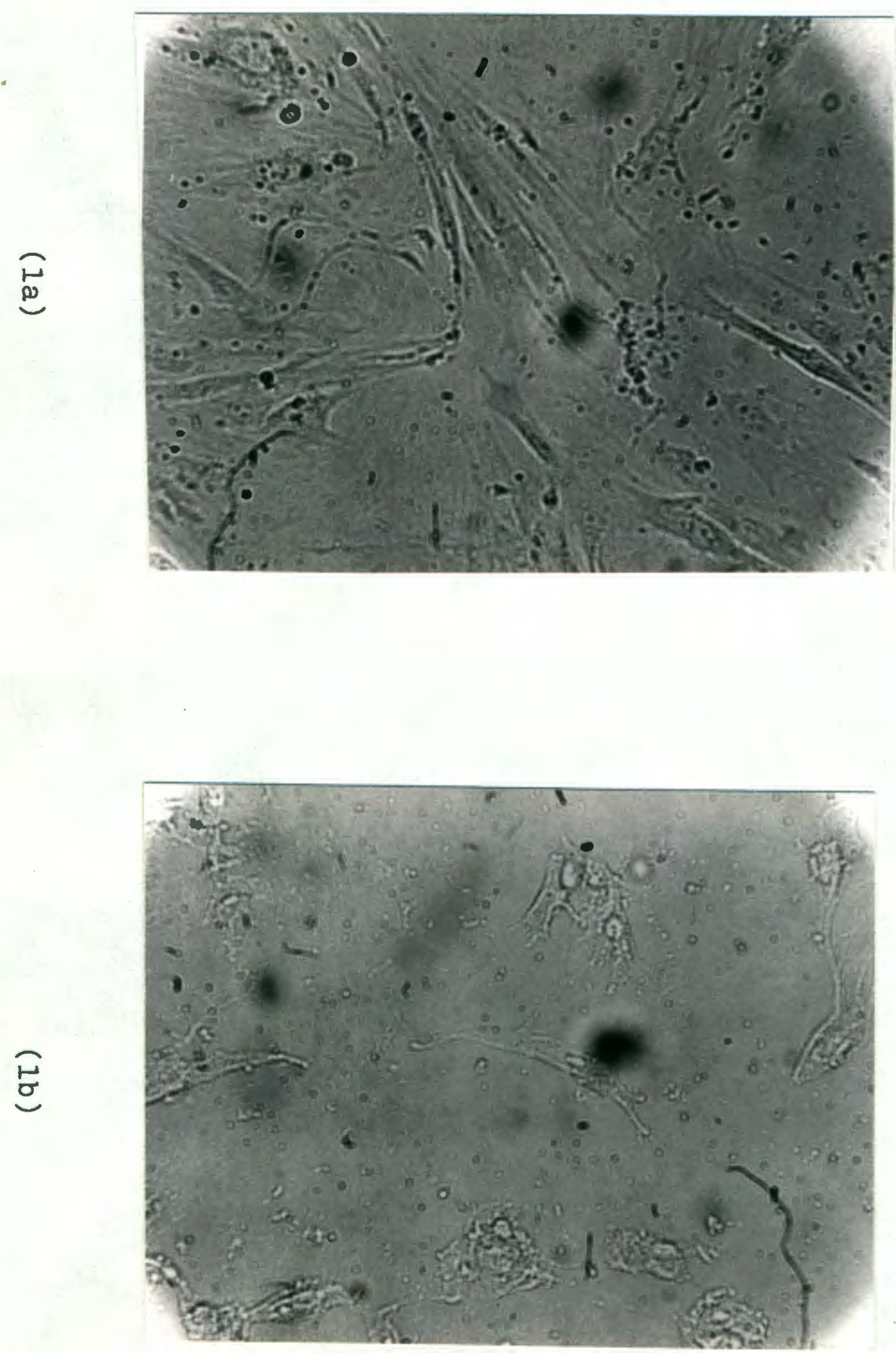

โ2 

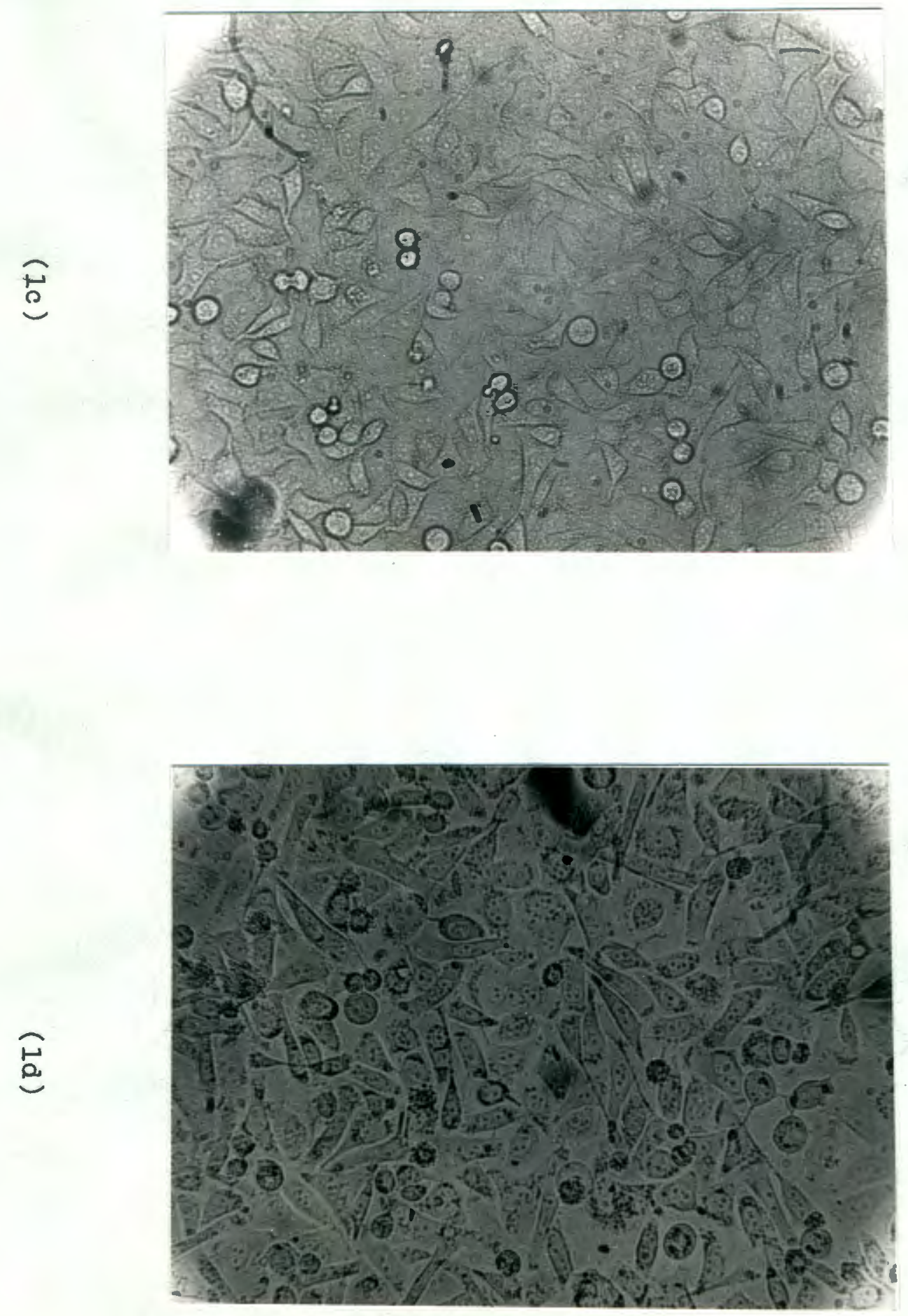
RESULTS OF CONTROL SYSTEMS AND DIFFERENT DILUTIONS OF RABBIT ANTIFIBROBLAST ANTISEPUH WITH COMPLEMENT ON CULTURES COMPOSED OF MIXED PIBROBLASTS AND

EPIXHELIAL CELIS DERIVED FROM HUMAN PROSTATIC TISSUES

\begin{tabular}{|c|c|c|c|c|c|c|c|c|}
\hline \multicolumn{5}{|c|}{ TEST SYSTEMS } & \multicolumn{4}{|c|}{ CONTROLS SYSTEMS } \\
\hline \multirow{2}{*}{$\begin{array}{c}\text { Rabbit } \\
\text { Antifibroblast } \\
\text { Antiserum } \\
\text { D1lutions }\end{array}$} & \multicolumn{4}{|c|}{ Complement D1lutione } & \multirow{2}{*}{$\begin{array}{l}\text { Cello } \\
\text { Alone }\end{array}$} & \multirow{2}{*}{$\begin{array}{l}\text { Rabb1t } \\
\text { Ant if } 1 \text { broblast } \\
\text { Antleerum Alone }\end{array}$} & \multirow{2}{*}{$\begin{array}{c}\text { Complement } \\
\text { Al one }\end{array}$} & \multirow{2}{*}{$\begin{array}{c}\text { Normal Rabolt } \\
\text { Serum }+ \\
\text { Complement }\end{array}$} \\
\hline & frocliluted & $1: 5$ & $1: 10$ & $1: 20$ & & & & \\
\hline Undiluted & + & + & ++ & +++ & - & - & - & - \\
\hline Diluted 1:2 & $++t$ & $t+t+$ & ++ & ++ & - & - & - & - \\
\hline
\end{tabular}

+ to +t+t Indicatod degree of cell lysis when $0.2 \mathrm{ml}$ of und1luted or rabbit antifibroblast antiserum diluted $1: 2$ and $1 \mathrm{ml}$ complement goncentrations ranging from und1luted to $1: 20$ were added to the mixed cultures of flbroblasto and epithelium obtained from human prostatic tiosues. H1gher dilutions of reactant were not made because antiserum and cell cultures were limiting. 
Many epithelial cells remalned in cultures following treatment of mixed cell type outgrowth with antifibroblast ant1serum and complement. These results were observed and recorded in photographs shown in Figure 2.

After many experimental assays using different dilutions of rabbit antifibroblast antiserum and complement, it was concluded that undiluted rabbit antifibroblast antiserum plus complement diluted 1:150 or rabbit antifibroblast antiserum diluted 1:5 plus complement diluted 1:75 provided very little evidence of fibroblast cell lysis. Because quantities of mixed cell cultures consisting of flbroblasts and epttheIial cells and the supply of rabbit antifibroblast antiserum were limiting other dilutions of reactants could not be carried out in thesestudies. Of the various dilutions of rabbit antifibroblast antiserum and complement, rabbit antifibroblast antiserum diluted $1: 2$ supplemented with complement diluted $1: 5$ provided the bestand most consistent effects in terms of promoting lysis of fibroblasts.

Purification of IgG Recovered from Rabbit Antifibroblast Antiserum and Normal Rabb1t Serum

By reference to the standard curve for proteln estimation, prepared according to the Lowry method and shown in Figure 3 , the protein content of the reconstituted fraction of antifibroblast antiserum after $\left(\mathrm{NH}_{4}\right)_{2} \mathrm{SO}_{4}$ precipitation was calculated to be $0.071 \mathrm{mg}$ protein per $0.4 \mathrm{mI}$ reaction mixture or $0.18 \mathrm{mg}$ per $\mathrm{ml}$. The proteln concentration of 
Figure 2. Photographic demonstration of selective effects of antifibroblast antiserum and complement on cultures of mixed cell types arising from explants of human prostatic tissues.

In these studies various concentrations of antifibroblast antiserum and complement were employed in order to find the most effective reagent proportions necessary to achieve fibroblast destruction. Procedures for culture treatment, Including control systems, were recorded in the Materials and Methods section. All cells were grown in Eagle's medium containing 20\% fetal bovine serum. Mixed cell type cultures were composed of cells exhlbiting epltheIlal and flbroblast-Iike morphologies. All antifibroblast antiserum was heat inactivated at $56^{\circ}$ for $30 \mathrm{~min}$. Magnif1cation $x I 60$.

Identification of photographs: All photographs designated with the letter "a" as from (1a) through (14a) were those cultures composed of mixed cell types which were photographed at zero tIme before treament. Photographs designated with the letter "b" were made of preparations treated in the varlous ways listed below.

(1b) Untreated control culture of mixed cell types photographed $23 \mathrm{hr}$ after zero time.

(2b) Mixed cell type culture photographed $23 \mathrm{hr}$ after treatment with undiuted antifibroblast antiserum only: 
an antiserum control.

(3b) Mixed cell type culture photographed 23 hr after treatment with complement only, diluted 1:20: a complement control.

(4b) Mixed cell type culture photographed 23 hr after treatment with undiluted normal rabbit serum and complement diluted 1:5: a normal rabbit serum control.

(5b) Mixed cell type culture photographed 23 hr after treatement with undiluted antifibroblast antiserum and undiluted complement.

(6b) Mixed cell type culture photographed 28 hr after treatment with undiluted antifibroblast antiserum and complement diluted $1: 5$.

(7b) M1xed cell type culture photographed 28 hr after treatment with undiluted antifibroblast antiserum and complement diluted $1: 10$.

(8b) Mixed cell type culture photographed 28 hr after treatment with undiluted antifibroblast antiserum and complement diluted $1: 20$.

(9b) Mixed cell type culture photographed 28 hr after treatment with undiluted antifibroblast antiserum and complement diluted $1: 30$.

(10b) Mixed celI type culture photographed $23 \mathrm{hr}$ after treatment with undiluted antifibroblast antiserum and complement diluted $1: 45$.

(11b) Mixed cell type culture photographed 23 hr after 
treatment with undiluted antifibroblast antiserum and complement d11uted 1:60.

(12b) Mixed cell type culture photographed 23 hr after treatment with undiluted antiIfbroblast antiserum and complement diluted 1:75.

(13b) Mixed cell type culture photographed 23 hr after treatment with undiluted antifibroblast antiserum and complement d11uted 1:150.

(14b) M1xed celI type culture photographed 23 hr after treatment with antifibroblast antiserum diluted $1: 2$ and complement diluted $1: 5$. 

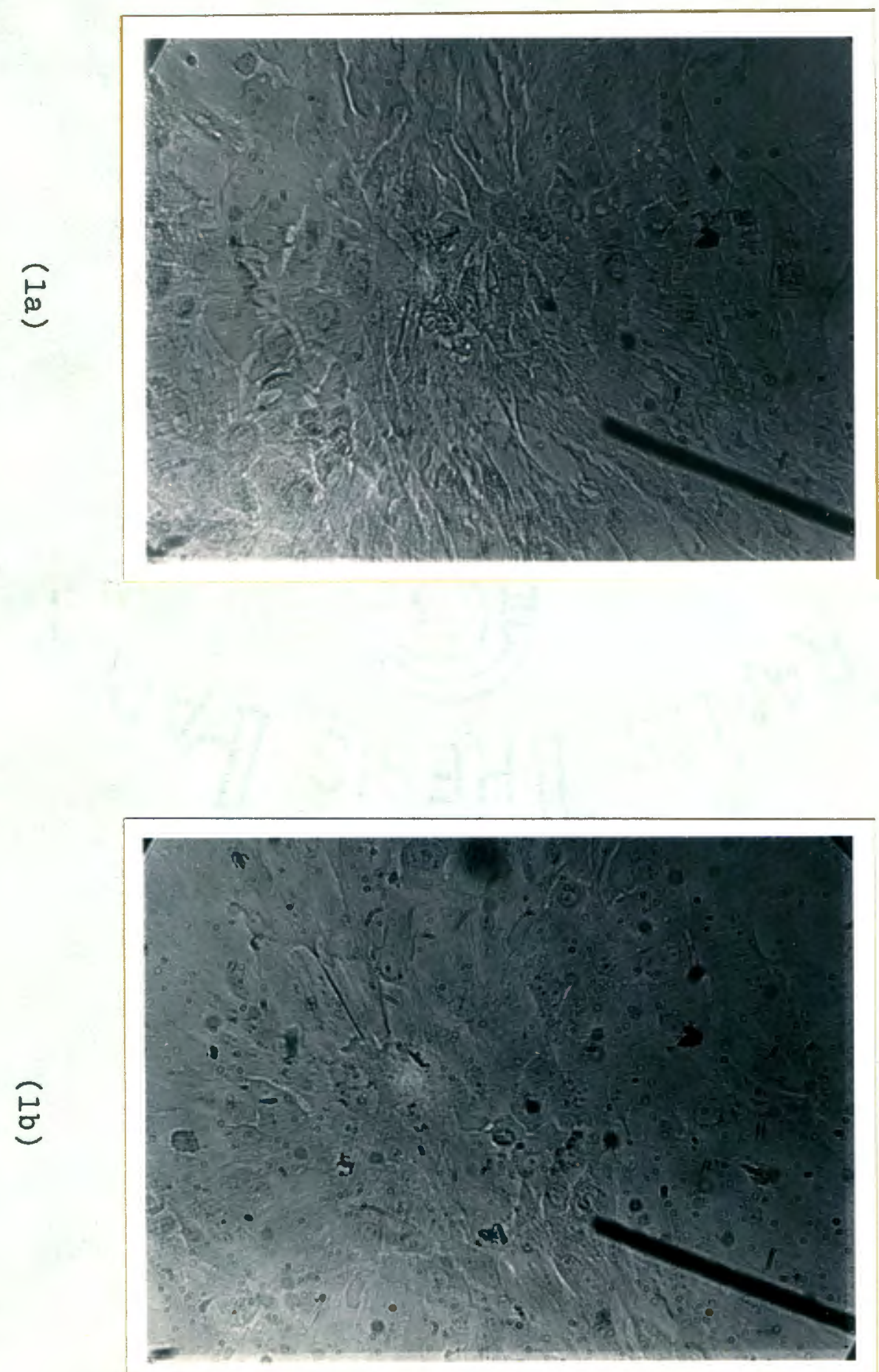

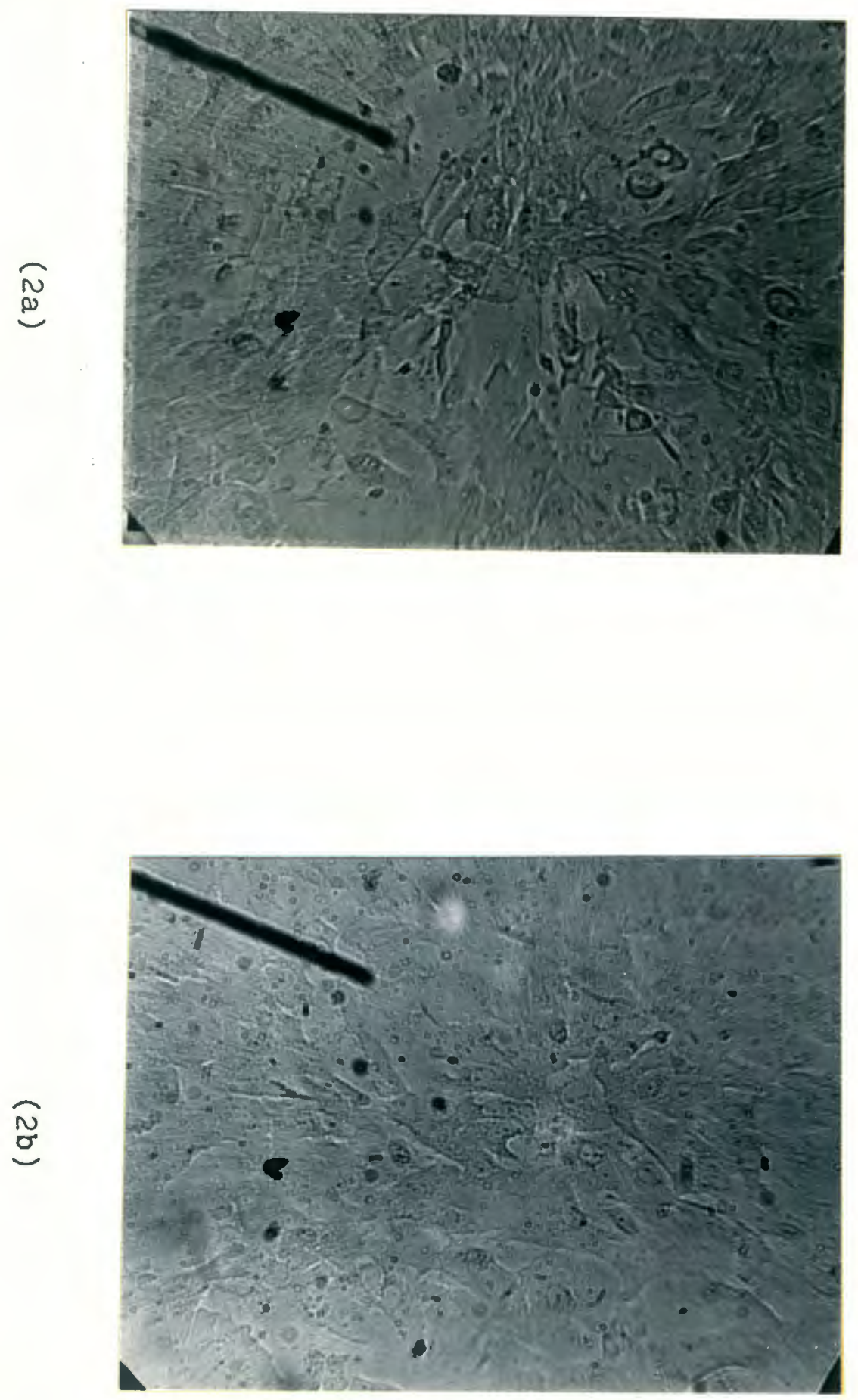
$\underset{\omega}{\omega}$
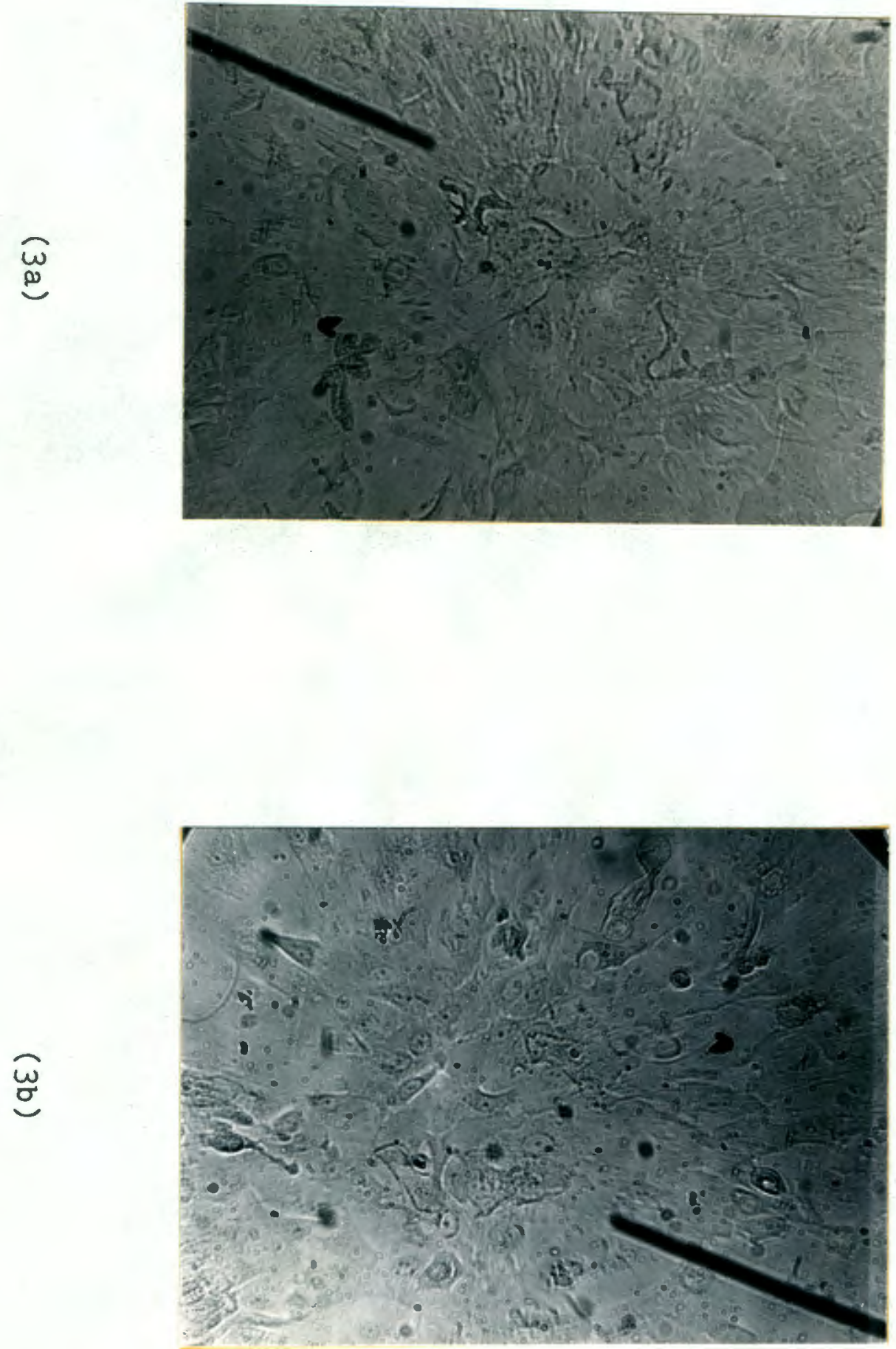

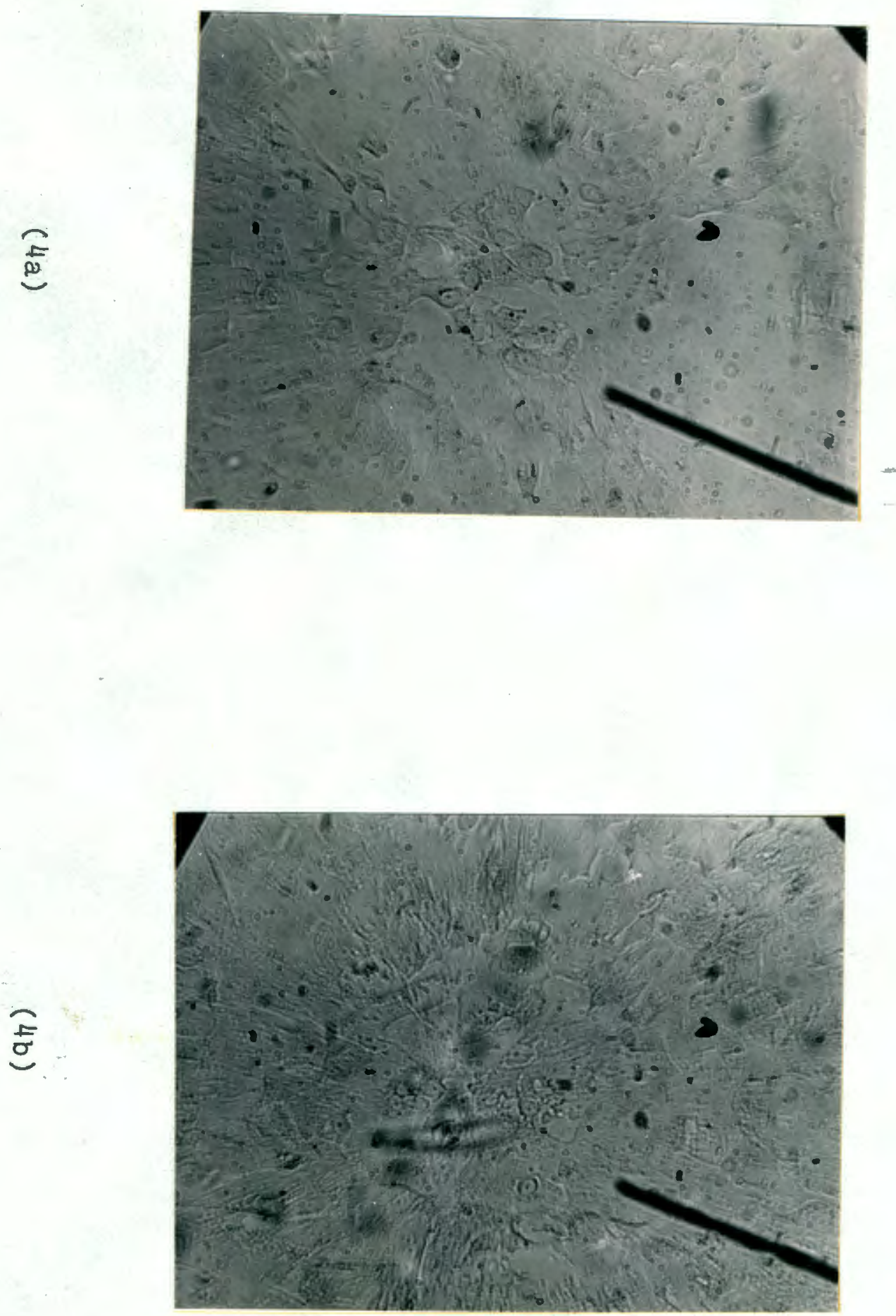

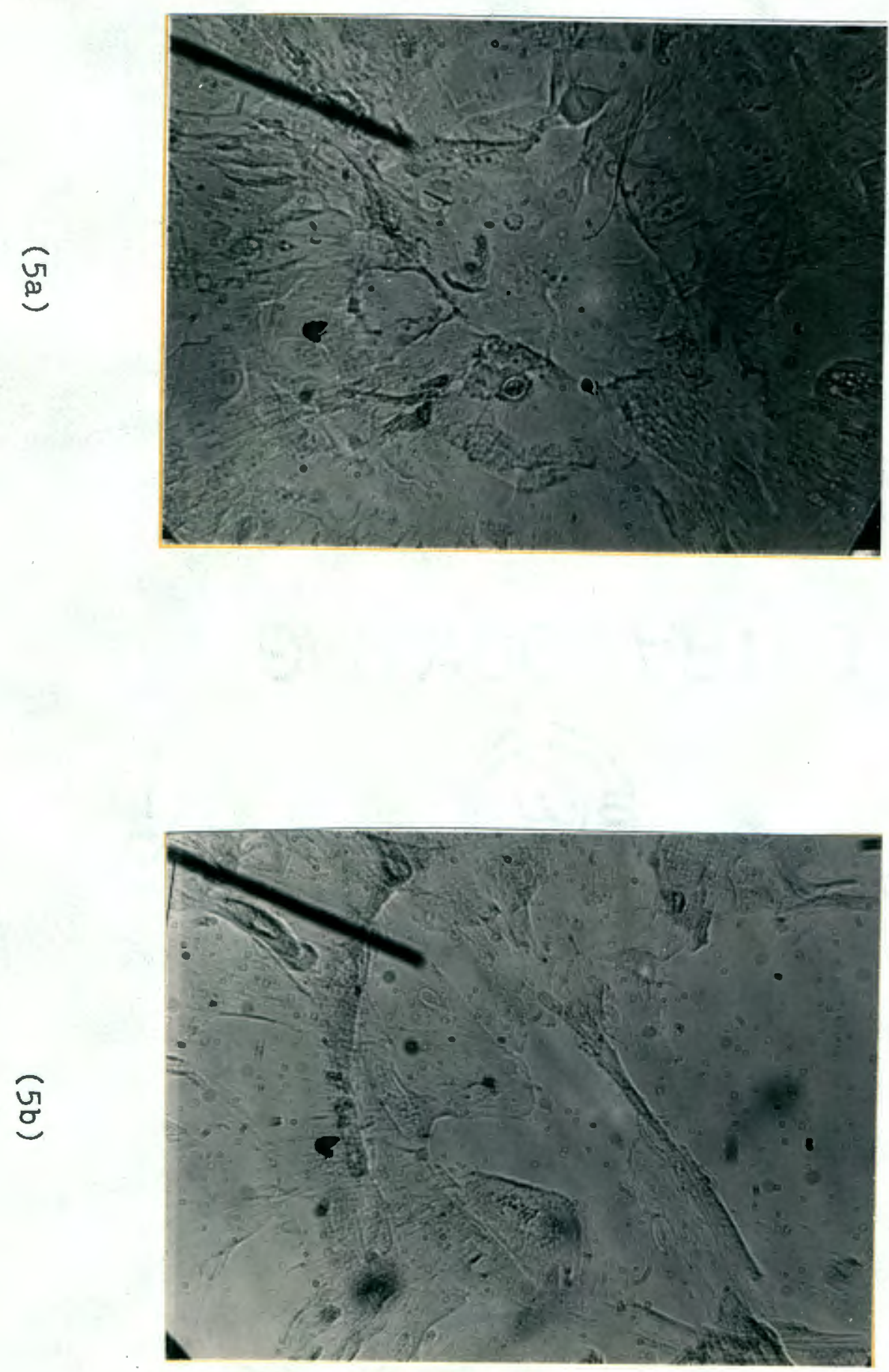

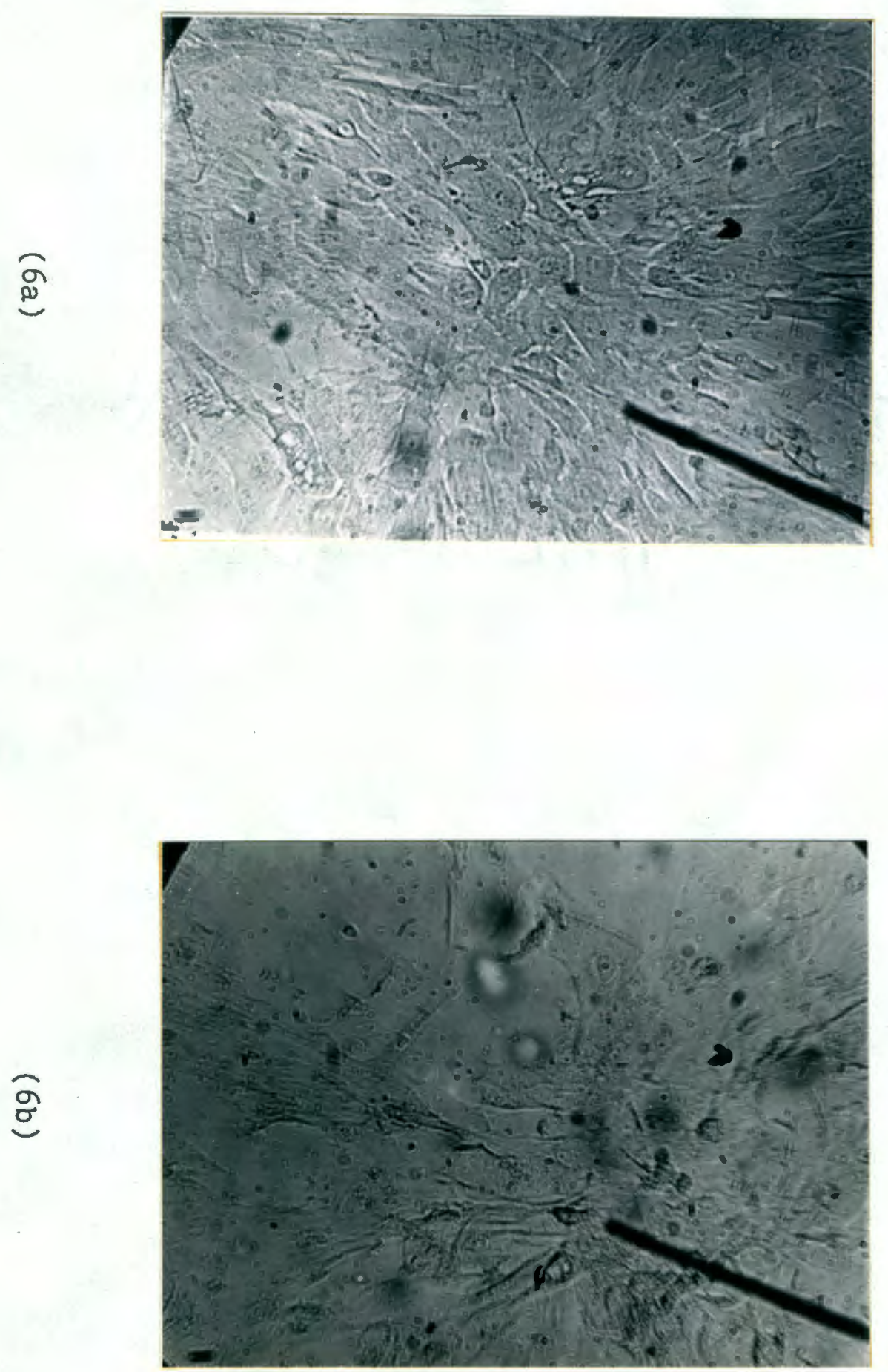

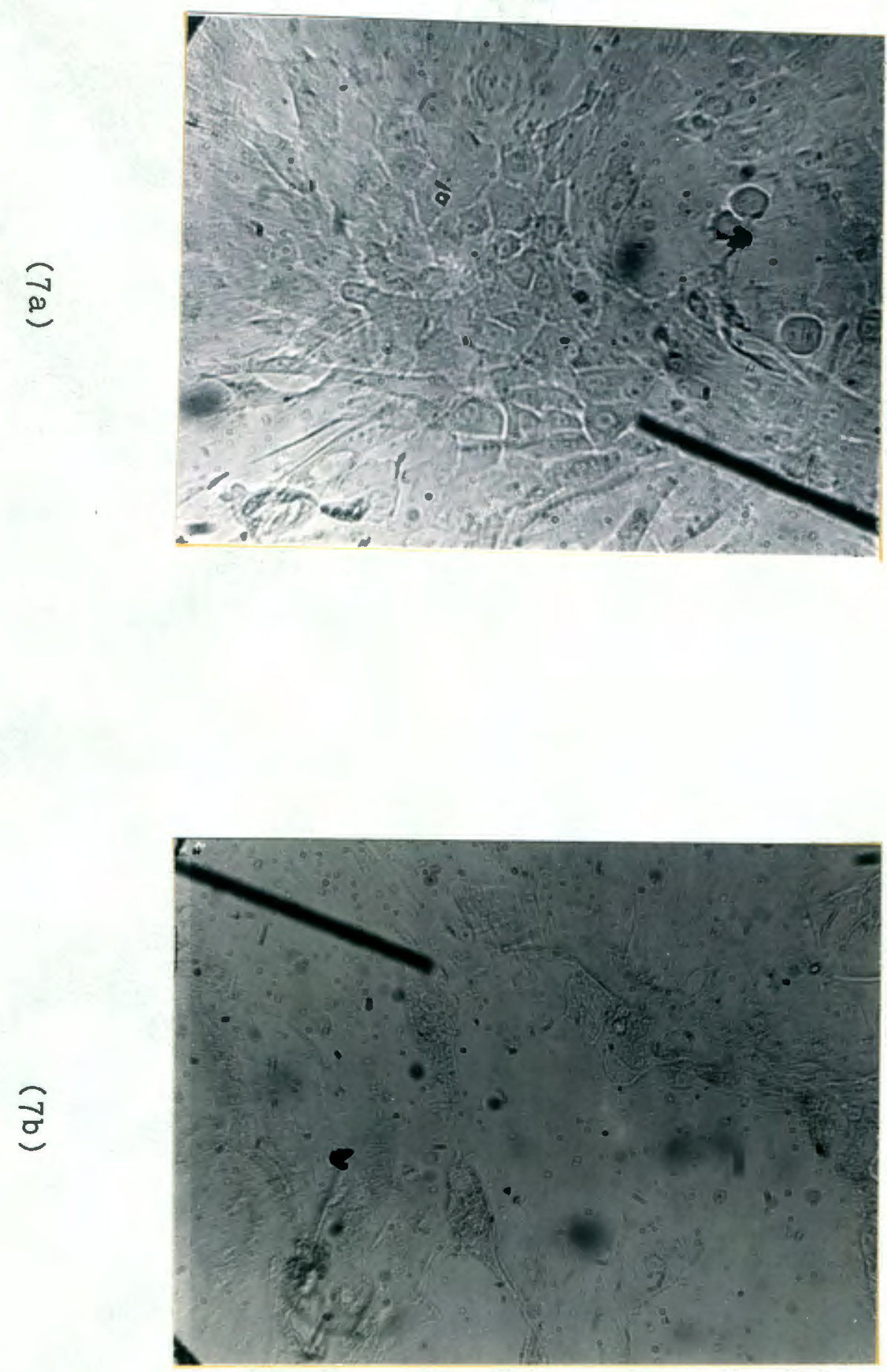

$\dagger \mathcal{E}$ 

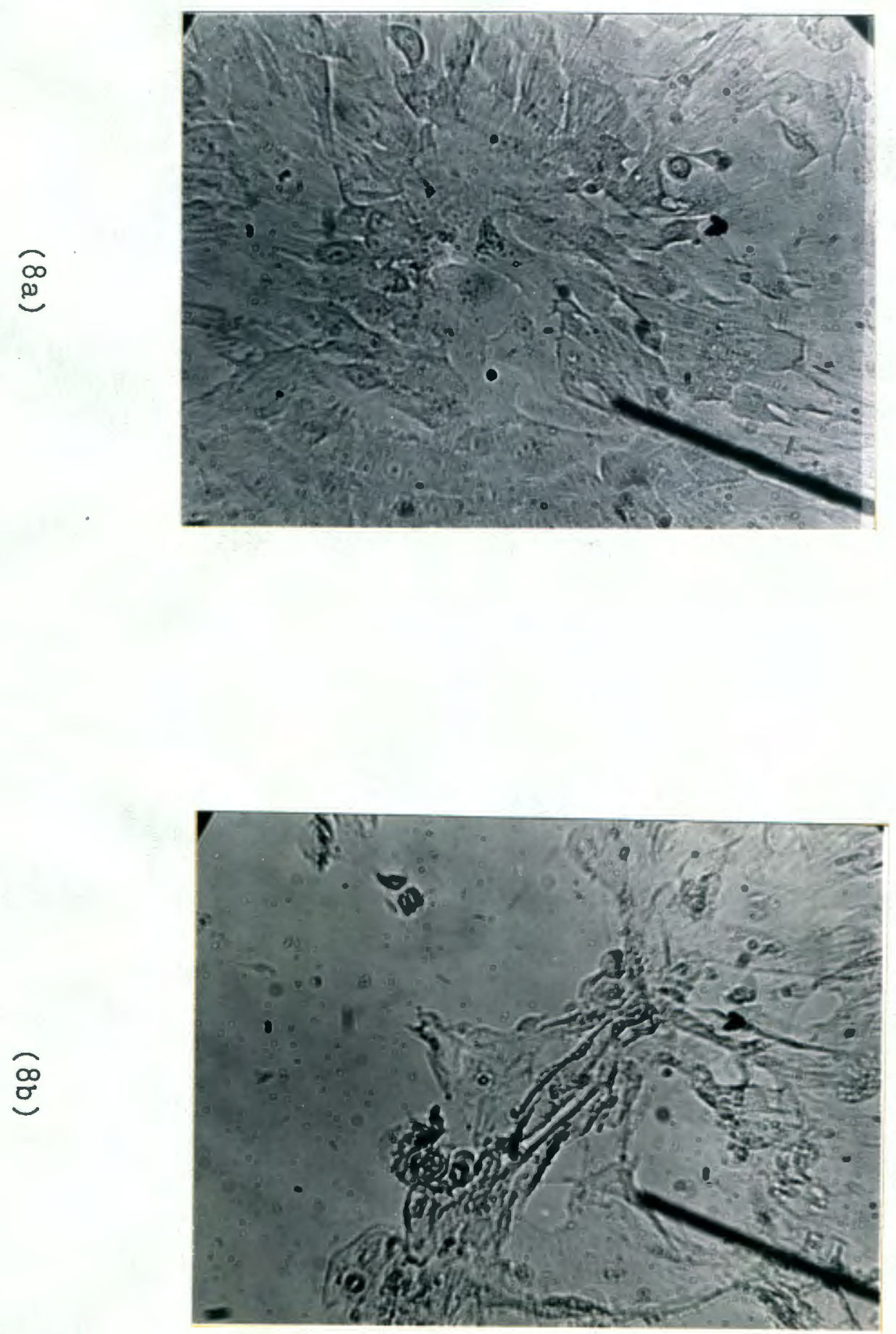

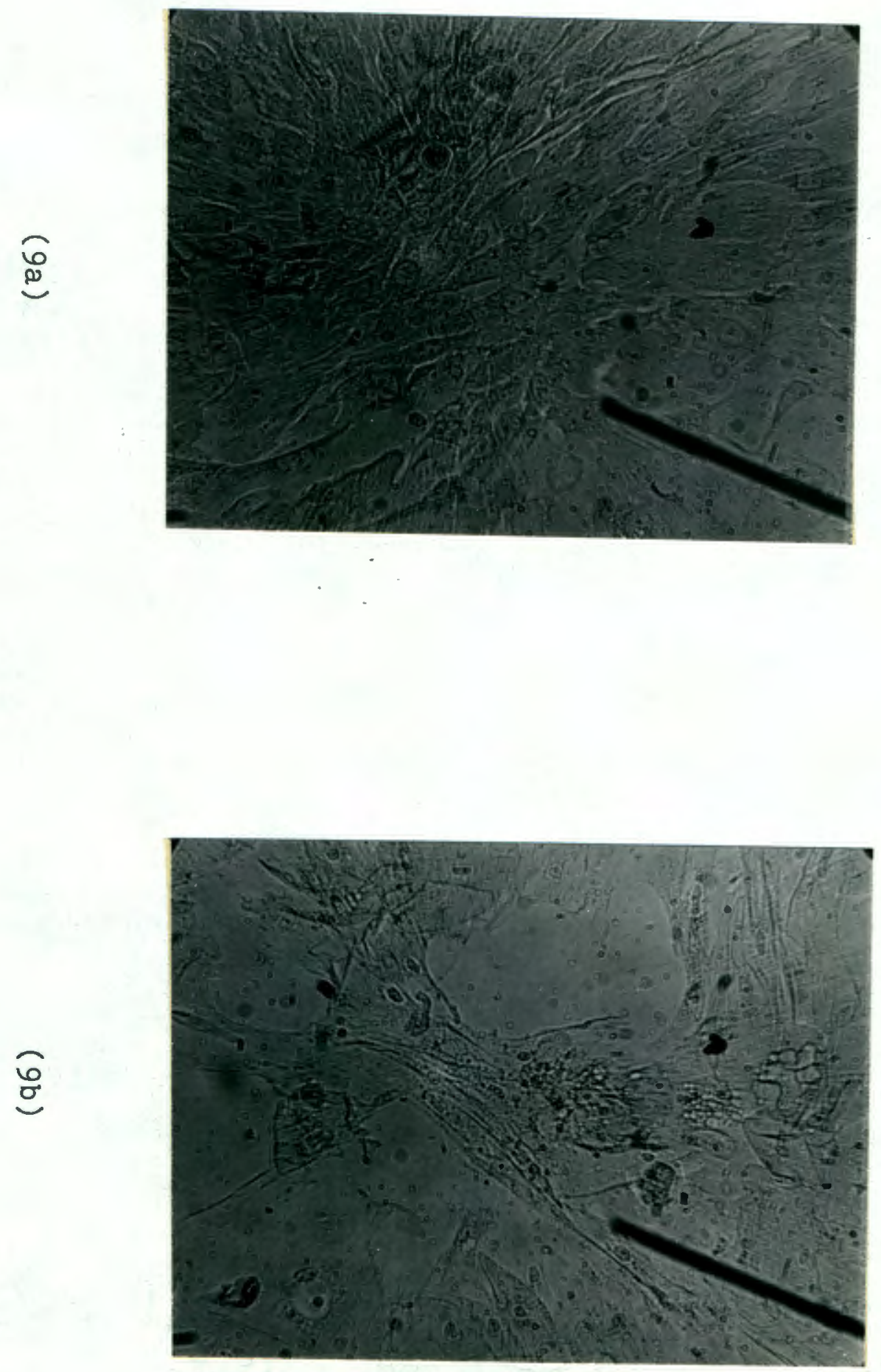

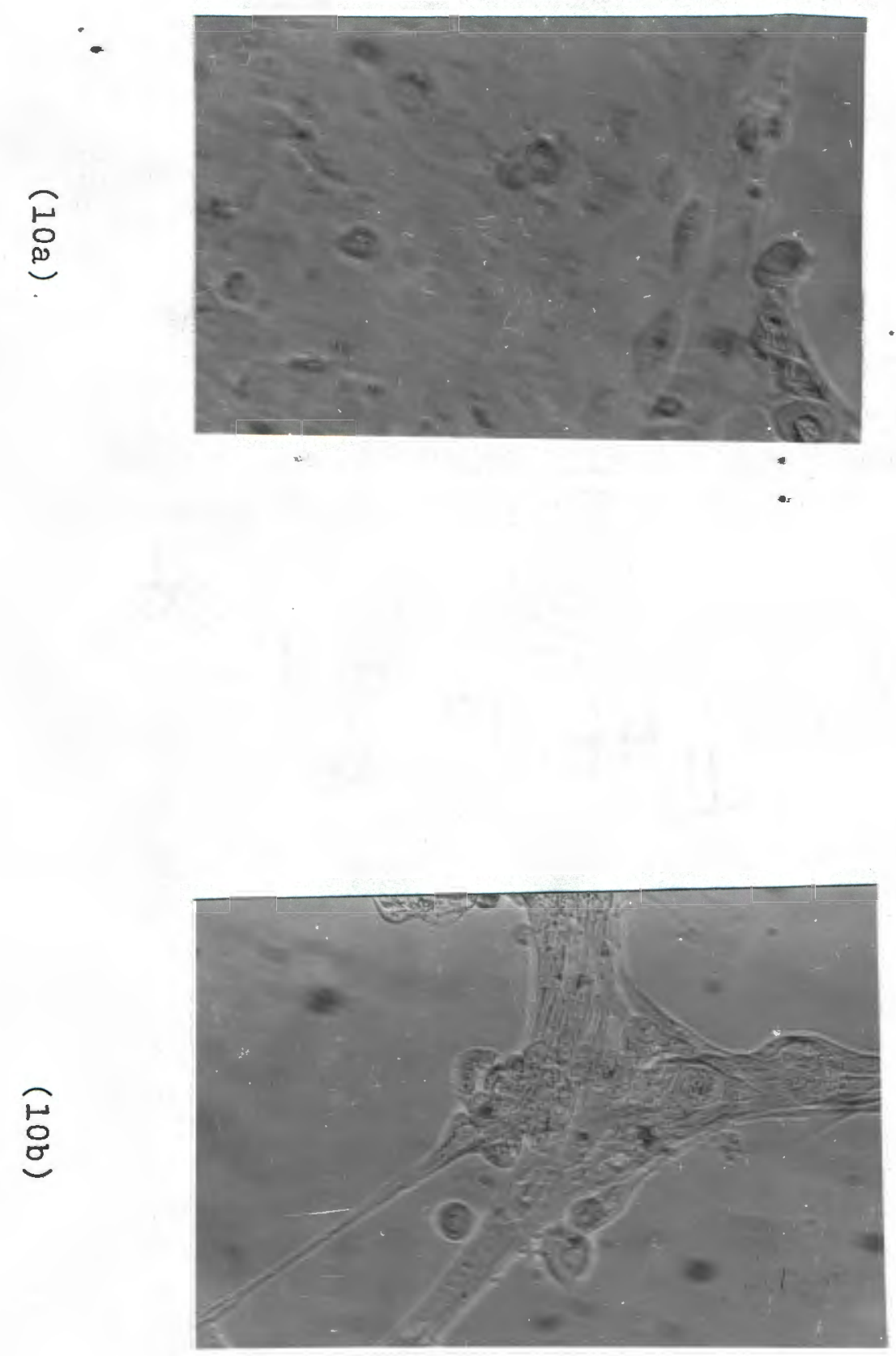

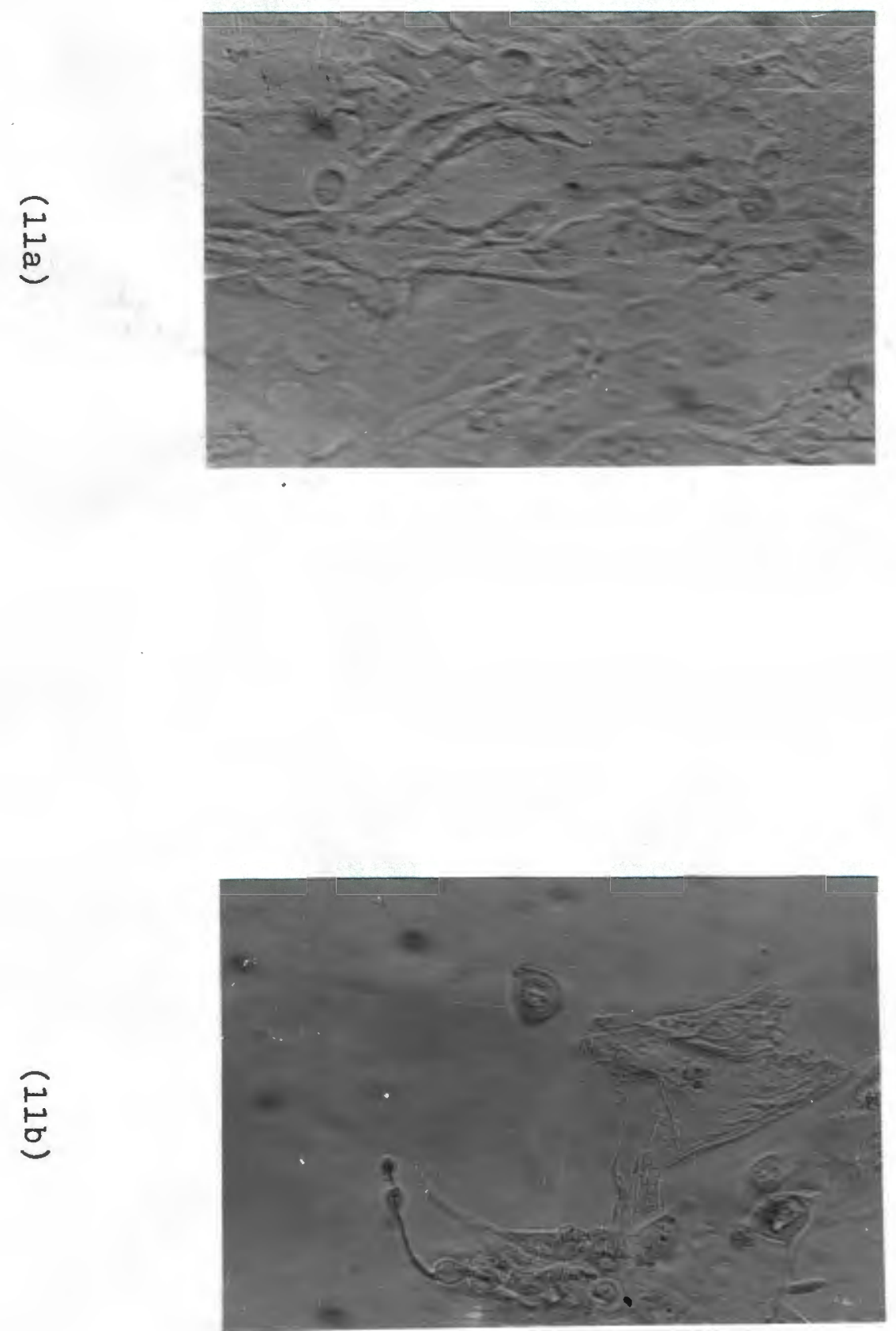

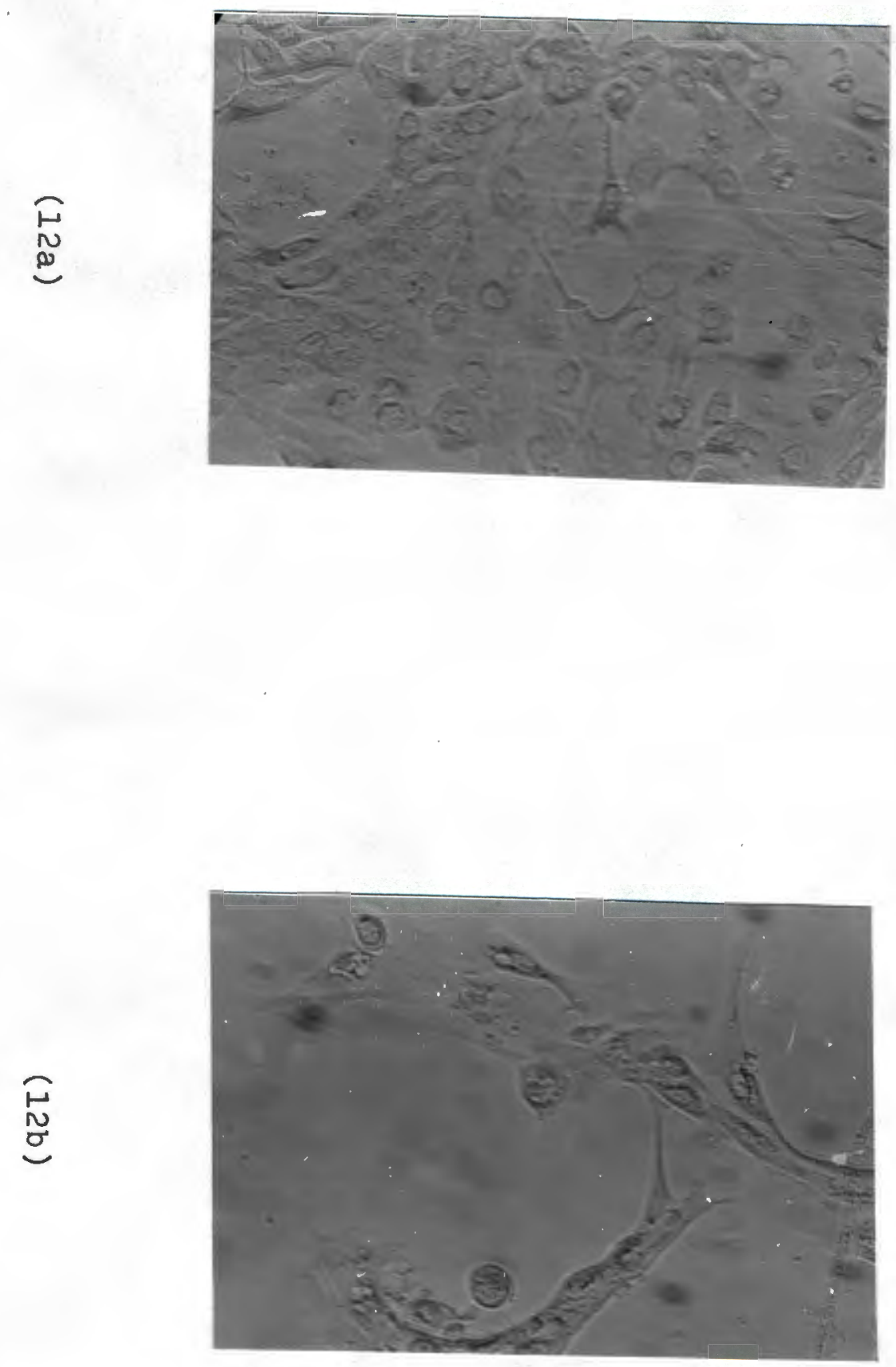

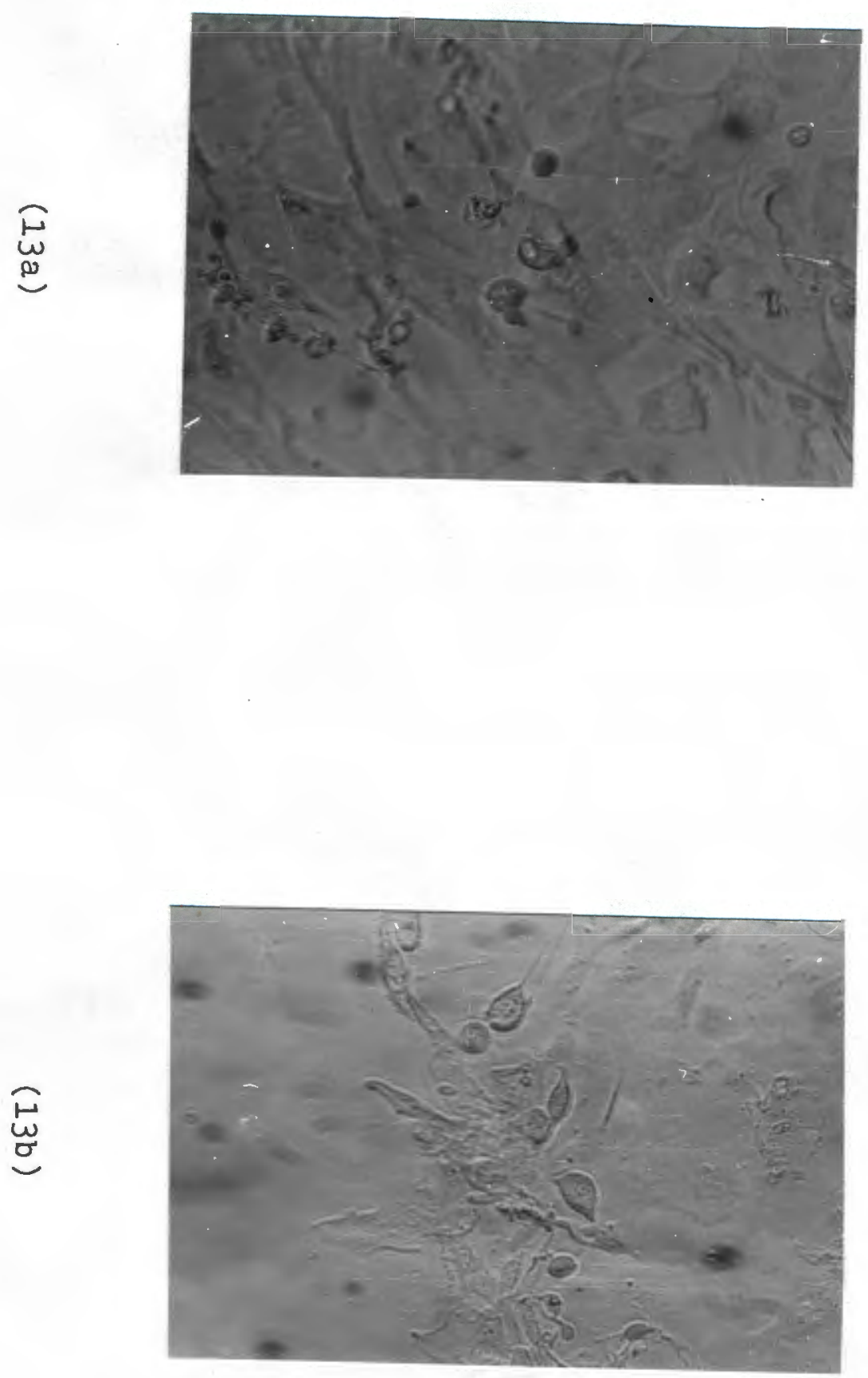

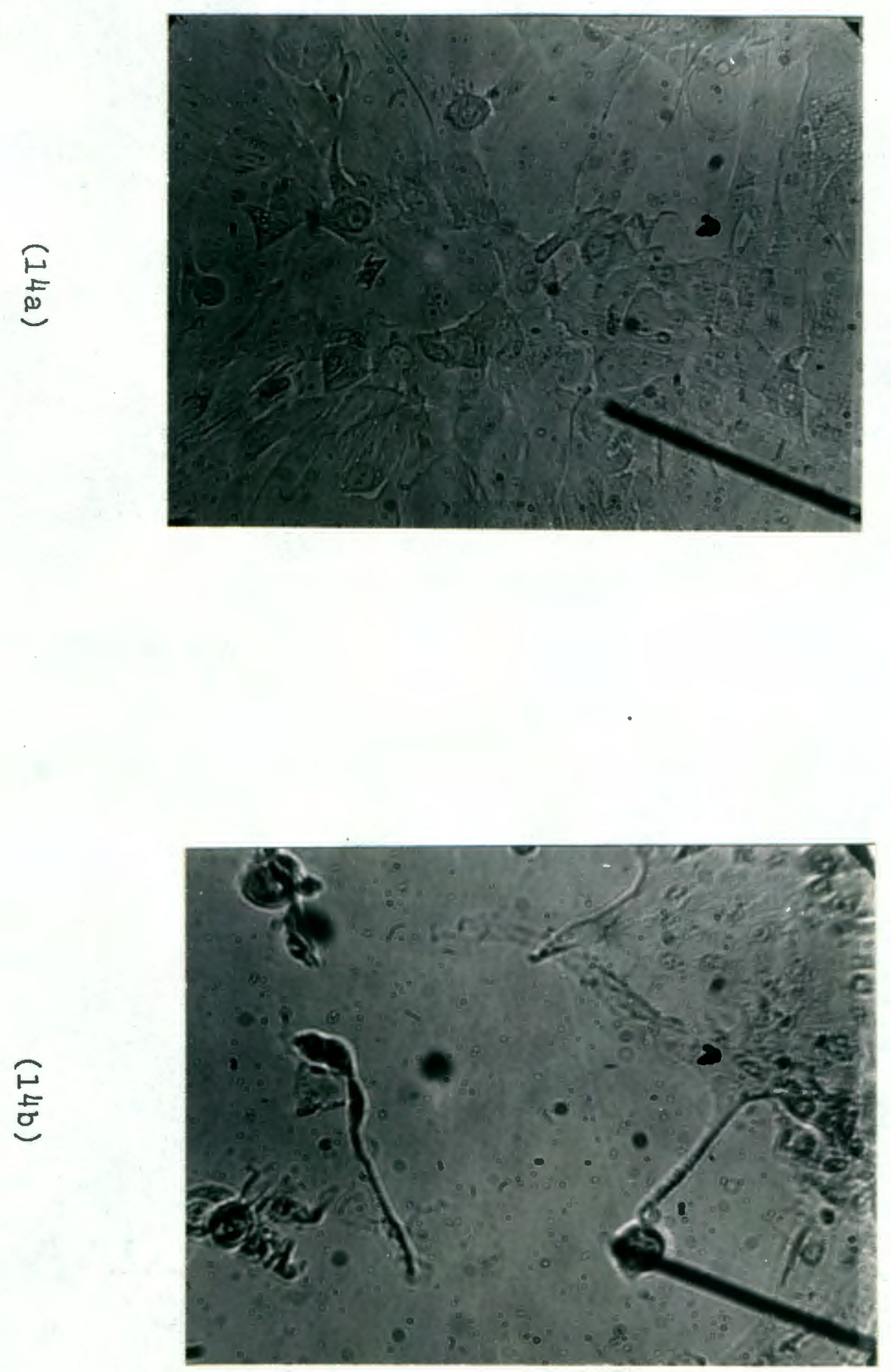


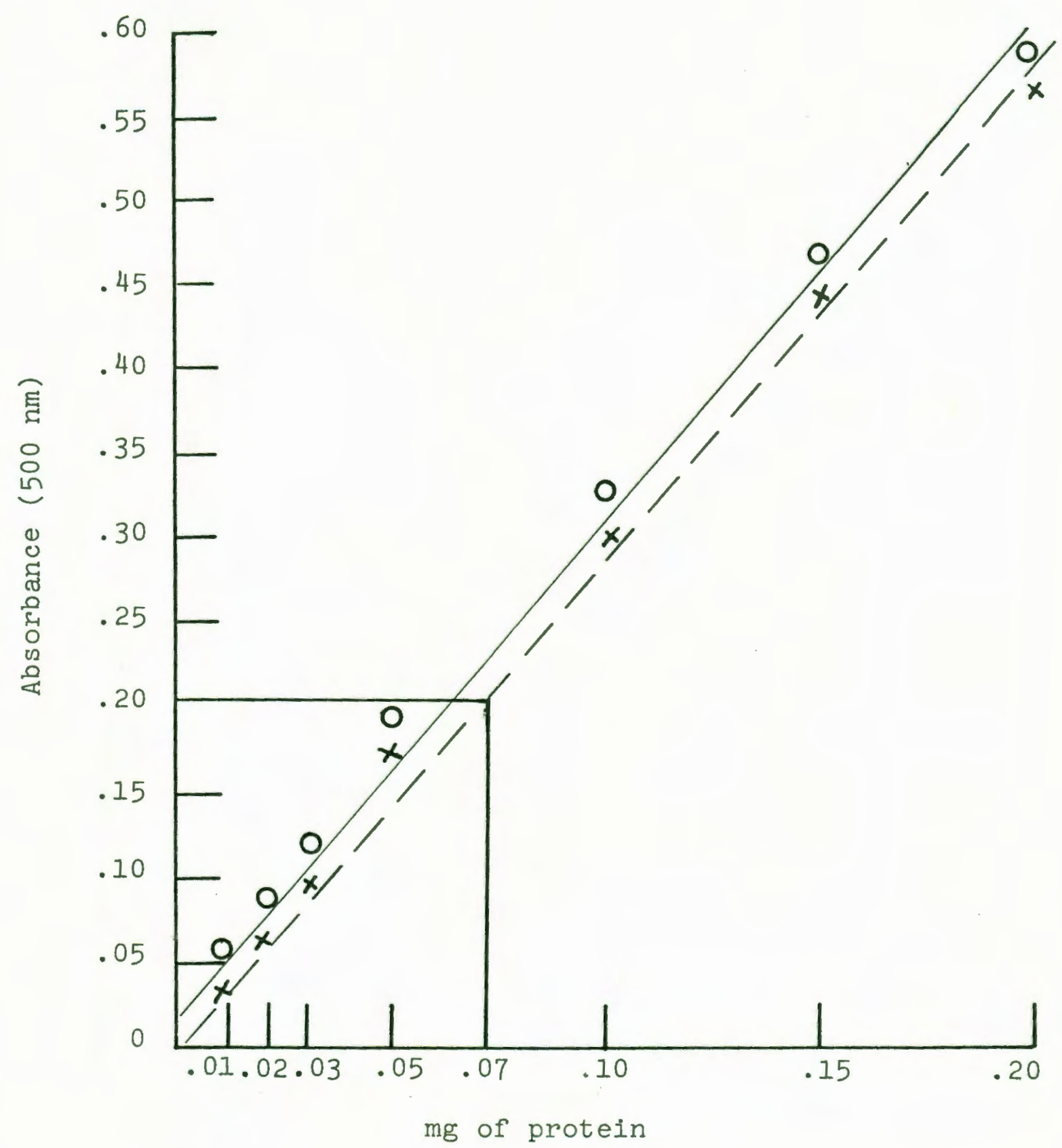

Figure 3. Standard curve as prepared by the Lowry method for protein estimation and used to calculate protein content of rabbit antifibroblast antiserum and that of fractions derived from it. 
purffled IgG recovered from antifibroblast antiserum was found to be $18 \mathrm{mg}$ per $\mathrm{ml}$.

As calculated from an appropriate Lowry standard curve for protein estimation shown in Flgure 4 the protein concentration of the reconstituted fraction of normal rabbit serum after $\left(\mathrm{NH}_{4}\right)_{2} \mathrm{SO}_{4}$ precipitation used in these experiments was found to be $0.066 \mathrm{mg}$ per $0.4 \mathrm{ml}$ reaction mixture or 0.17 mg per $\mathrm{ml}$. Purified IgG isolated from normal rabbit serum contained $17 \mathrm{mg}$ protein per $\mathrm{ml}$.

Purification of Gamma GIobuIin Isolated from Rabbit Antifibroblast Antiserum by DEAE CeIlulose Column Chromatography

As seen in Figure 5, a single peak representing partially purified gamma globulin was separated from rabbit antifibroblast antiserum and removed from the antiserum by DEAE cellulose column chromatography. High ultraviolet (UV) absorbing $(280 \mathrm{~nm})$ spectrophotometric readings suggested that significant amounts of protein were present in samples recovered from the peak area displayed in Figure 5. The average protein concentration of eluted solutions showing UV absorption at $280 \mathrm{~nm}$ was calculated to be $0.29 \mathrm{mg}$ per $\mathrm{ml}$. 


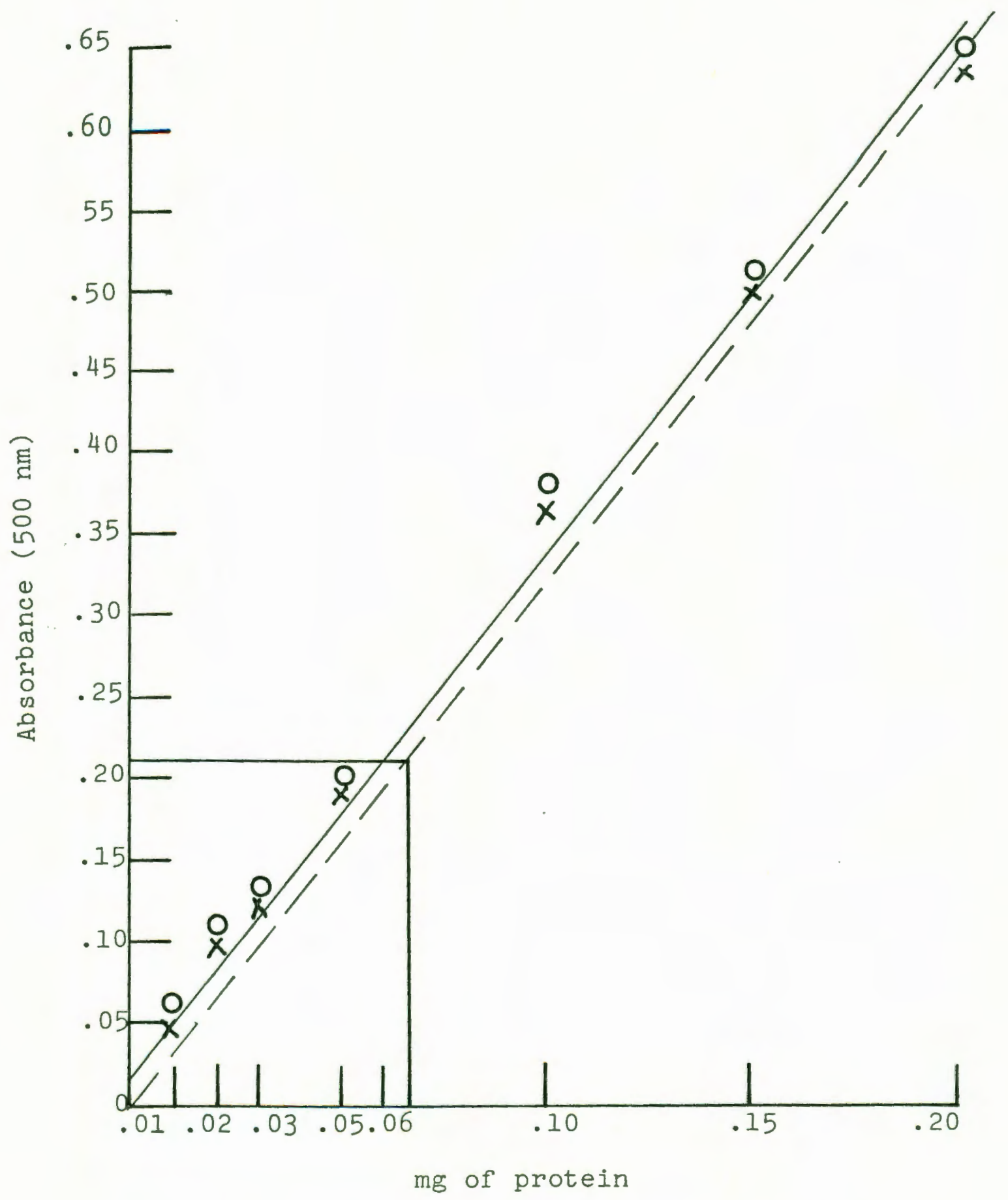

Figure 4. Standard curve as prepared by the Lowry method for protein estimation and used to calculate protein content of nomal rabbit serum and that of fractions derived from it. 


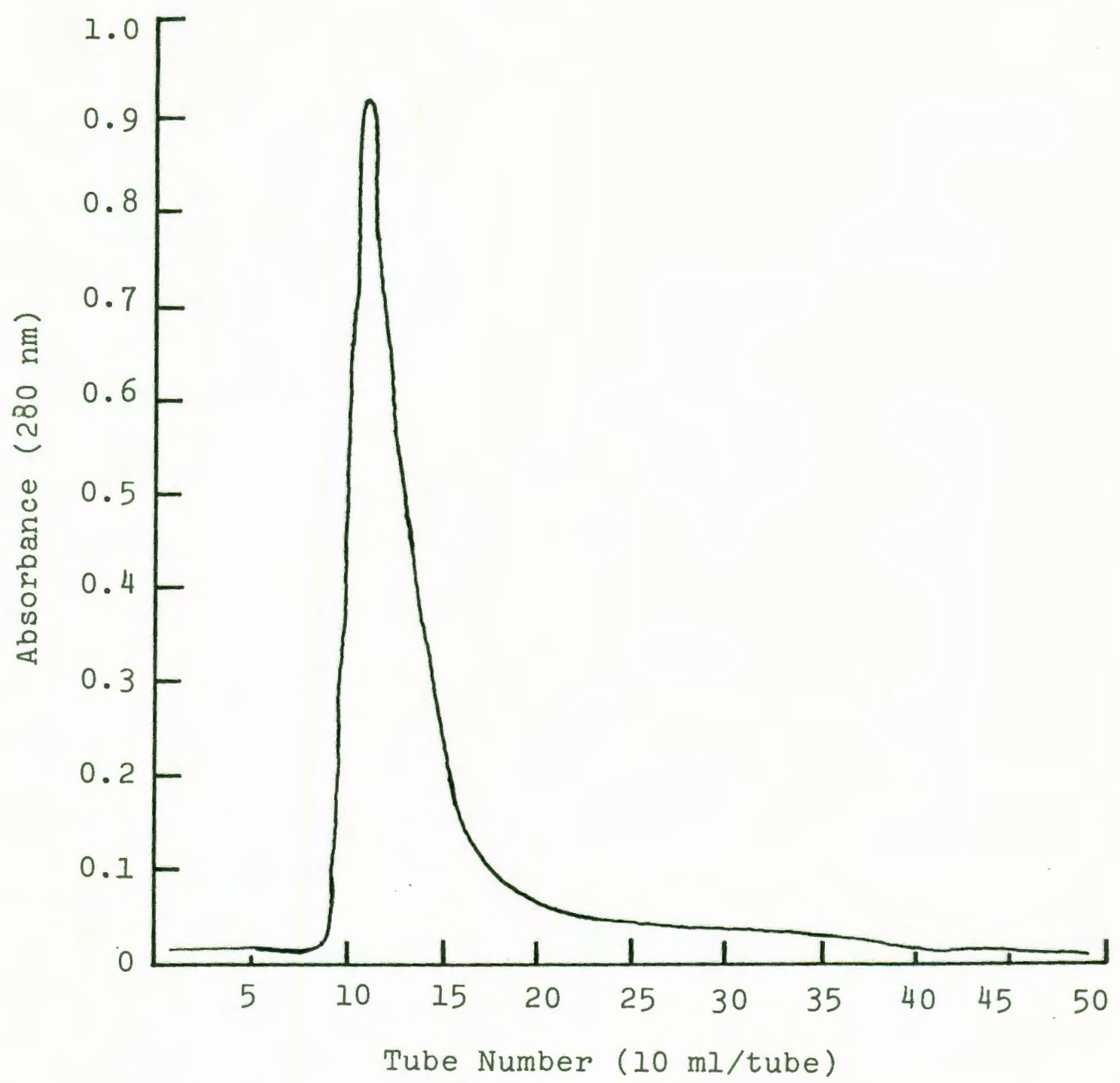

Figure 5. Tracing of a partially purified peak of gamma globulin isolated from rabbit antifibroblast antiserum by DEAE cellulose column chromatography.

Data recorded in Figure 5 represented UV absorption values (read at $280 \mathrm{~nm}$ ) vs volume. DEAE cellulose column was equilibrated in $0.01 \mathrm{M}$ phosphate buffer, $\mathrm{pH} 7.5$. 
Analytical UItracentrifugation Information Used to

Characterize Gamma GIobulin Isolated from Rabblt Antifibro-

blast Antiserum by DEAE Cellulose Column Chromatography

Part1ally purifled gamma globulin recovered from antiflbroblast antiserum was centrifuged in the ModeI E Spinco Analytical Ultracentrifuge as stated in the Materlals and Methods section in order to obtain sufficlent information for sedimentation coefficient calculations. Photographs were made at $8 \mathrm{~min}$ intervals and scale readings were measured in $\mathrm{cm}$ as recorded in Table VI. $\log _{10} \mathrm{x}$ values were determined by using appropriate $\log _{10}$ tables.

Using $\log _{10}$ values vs time in $\mathrm{min}$, as recorded in Table VI it was possible to determine the slope of the line. A plot of the slope was recorded in Figure 6 .

$$
\begin{aligned}
& \text { Equation: } s=\frac{1}{w^{2} r} \times \frac{d r}{d t}=\frac{2.303}{60 w^{2}}\left(\frac{d \log x}{d t^{\prime}}\right) \\
& \frac{d \log x}{d t^{\prime}}=\frac{0.8338-0.7850}{80}=6.1 \times 10^{-4} \\
& \text { at } 56,000 \mathrm{rpm}, \frac{2.303}{60 \mathrm{w}^{2}}=1.116 \times 10^{-9}
\end{aligned}
$$

The sedimentation coefficlent of IgG obtained from normal rabbit serum was reported by others to be approximately 6.6. However such measurements were made under totally standard conditions. Observations for the rabbit antifibroblast antiserum IgG fraction were not made under 
DATA REQUIRED FOR THE CALCULATION OF THE SEDIMENTATION COEFFICIENT OF IgG ISOLATED FROM RABBIT

ANTIFIBROBLAST ANTISERUM

\begin{tabular}{|c|c|c|c|c|}
\hline Frame & Number & Time (interval in $\mathrm{min}$ ) & Scale Reading (cm) & $\log _{10} x$ \\
\hline & $1-1$ & 8 & 6.095 & 0.7850 \\
\hline & $1-2$ & 8 & 6.17 & 0.7903 \\
\hline & $1-3$ & - & $-\cdots$ & $-\cdots-\infty$ \\
\hline & $1-4$ & 8 & 6.32 & 0.8007 \\
\hline & $1-5$ & 8 & 6.42 & 0.8075 \\
\hline & $2-1$ & 8 & 6.57 & 0.8176 \\
\hline & $2-2$ & 8 & 6.67 & 0.8241 \\
\hline & $2-3$ & - & $-\cdots-$ & $-\cdots--$ \\
\hline & 2.4 & 8 & 6.72 & 0.8274 \\
\hline & $2-5$ & 8 & 6.82 & 0.8338 \\
\hline
\end{tabular}




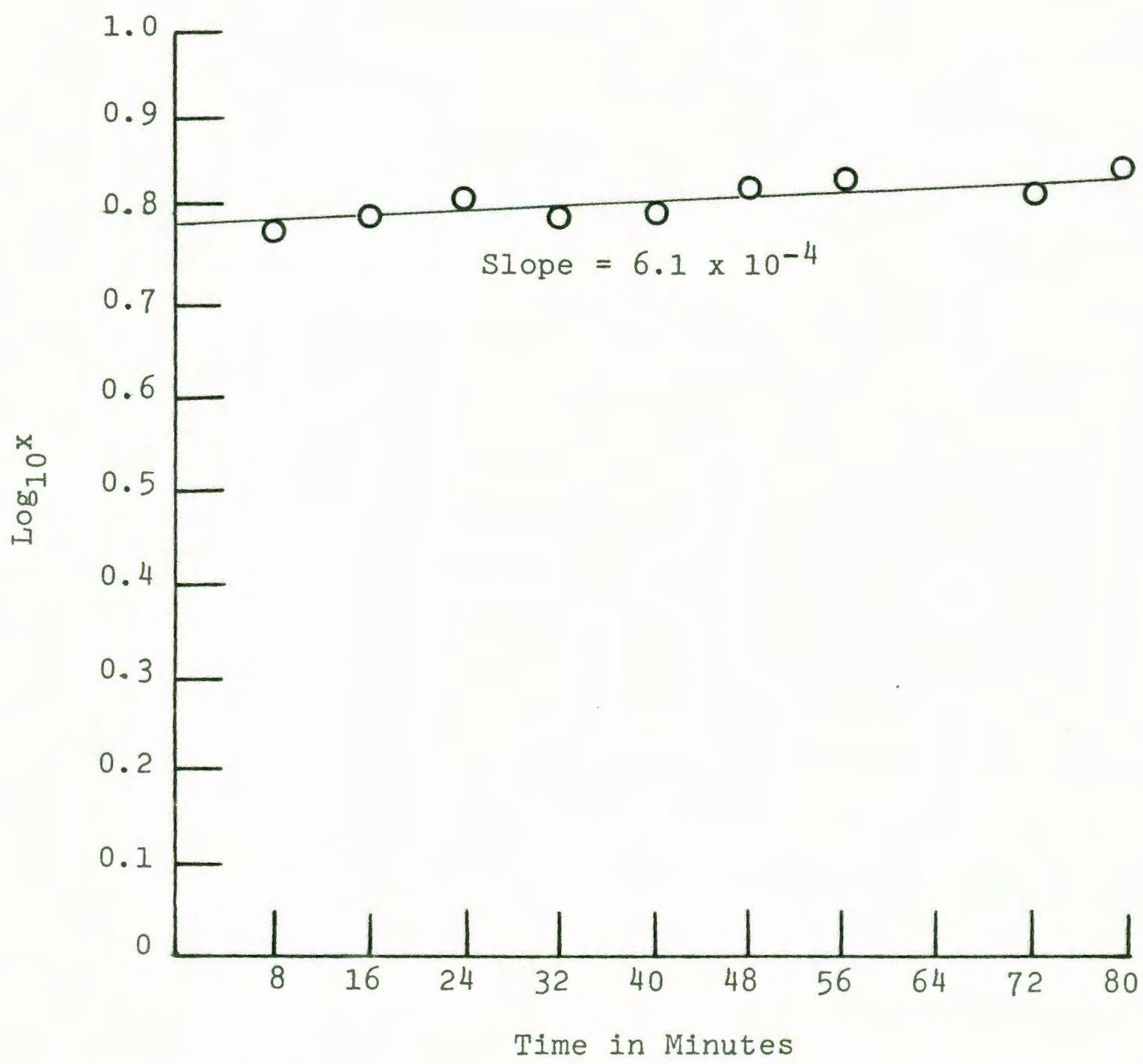

Figure 6. Plot of $\log _{10} \mathrm{x}$ versus $t$ as used for the calculation of a sedimentation coefficient for gamma globulin (IgG) isolated from antifibroblast antiserum. 
rigidiy controlled conditions which probably accounted for the small difference in $S$ values. From these data it was evident that the gamma globulin fraction obtained from rabbit antifibroblast antiserum was IgG.

Purification of Garma Giobulin Isolated from Normal Rabbit Serum by DEAE Celiulose Column Chromatography

Again a single peak of partially purffled gamma globulin, as shown in Figure 7, was obtained from normal rabbit serum. High UV absorbing values when measured spectrophotometrically at $280 \mathrm{~nm}$ were obtained. The average concentration of UV absorbing substance in peak solutions was calculated to be $0.27 \mathrm{mg}$ per $\mathrm{ml}$.

Analytical Ultracentrifugation Data Used to Characterize Gamma Giobulin Isolated from Normal Rabbit Serum by DEAE Cellulose Column Chromatography

As reported for similiar studies with IgG obtalned from rabbit antifibroblast antiserum partially purified gamma globulin recovered from normal rabbit serum was centrifuged In the Model E Splnco Analytical Ultracentrifuge. Photographs were made at $8 \mathrm{~min}$ intervals and scale readings were measured in $\mathrm{cm}$ as recorded in Table VII. Log $10 \mathrm{x}$ values were determined by using appropriate $\log _{10}$ tables.

Using $\log _{10}$ values vs time in $\mathrm{min}$, as recorded in Table VII the slope of the Iine was determined. A plot of the slope was recorded in Figure 8 and the $S$ value was 


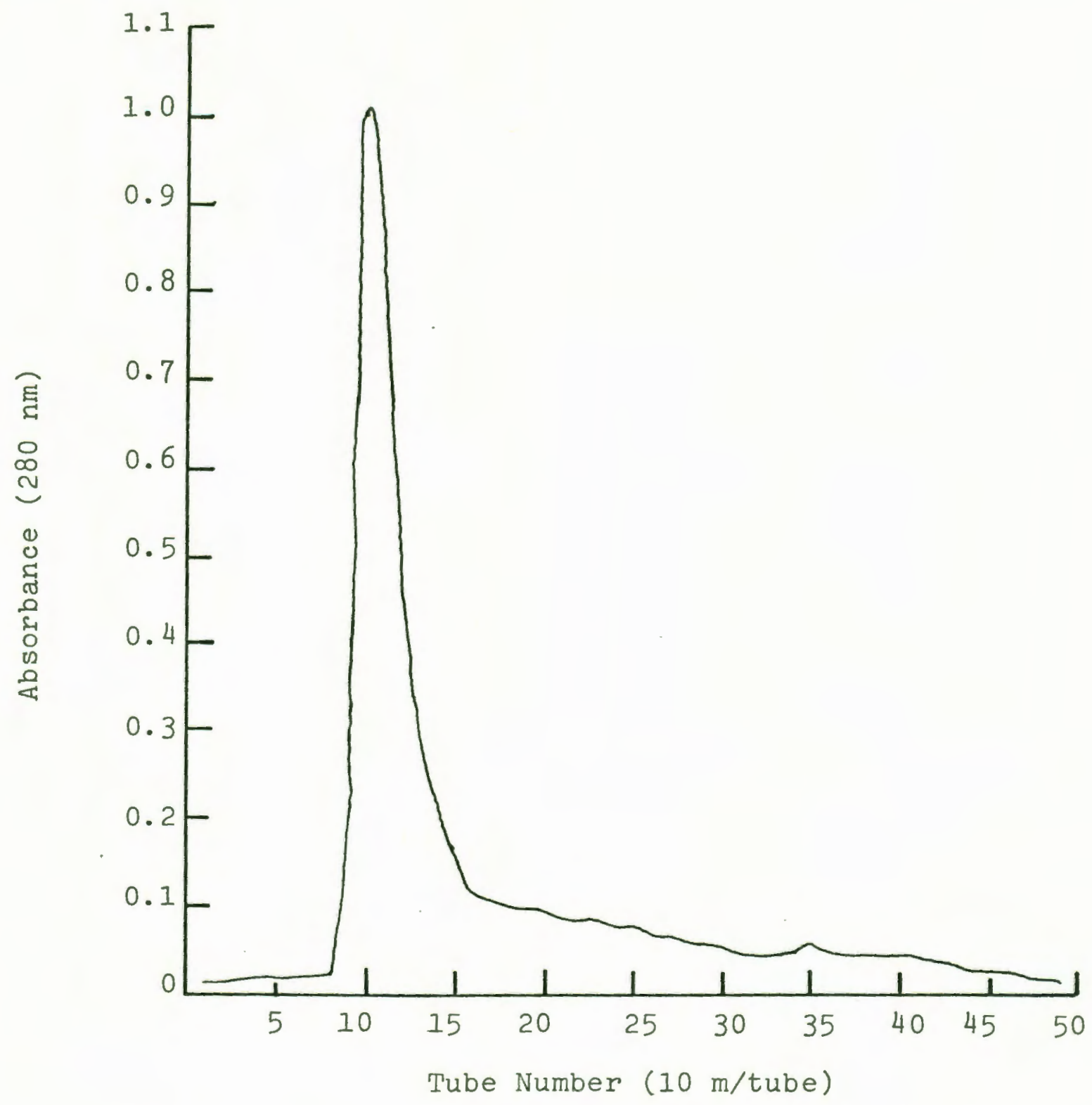

Figure 7. Tracing of a partially purified peak of gamma globulin isolated from normal rabbit serum by DEAE cellulose column chromatography.

Data recorded in Figure 7 represented UV absorption values (read at $280 \mathrm{~nm}$ ) vs volume. DEAE cellulose column was equilibrated in $0.01 \mathrm{M}$ phosphate buffer, $\mathrm{pH} 7.5$. 
DATA REQUIRED FOR THE CALCULATION OF THE SEDIMENTATION COEFFICIENT OF IgG ISOLATED FROM NORMAL RABBIT SERUM

\begin{tabular}{cccc}
\hline Frame Number & Time (Interval in min) & Scale $\operatorname{Reading}(\mathrm{cm})$ & $\log _{10} x^{-}$ \\
\hline $1-1$ & 8 & 5.995 & 0.7778 \\
$1-2$ & 8 & 6.08 & 0.7839 \\
$1-3$ & 8 & 6.15 & 0.7889 \\
$1-4$ & 8 & 6.22 & 0.7938 \\
$1-5$ & 8 & 6.295 & 0.7990 \\
$2-1$ & 8 & 6.38 & 0.8048 \\
$2-2$ & 8 & 6.47 & 0.8109 \\
$2-3$ & 8 & 6.52 & 0.8142 \\
$2-4$ & 8 & 6.62 & 0.8209 \\
$2-5$ & 8 & 6.695 & 0.8257
\end{tabular}




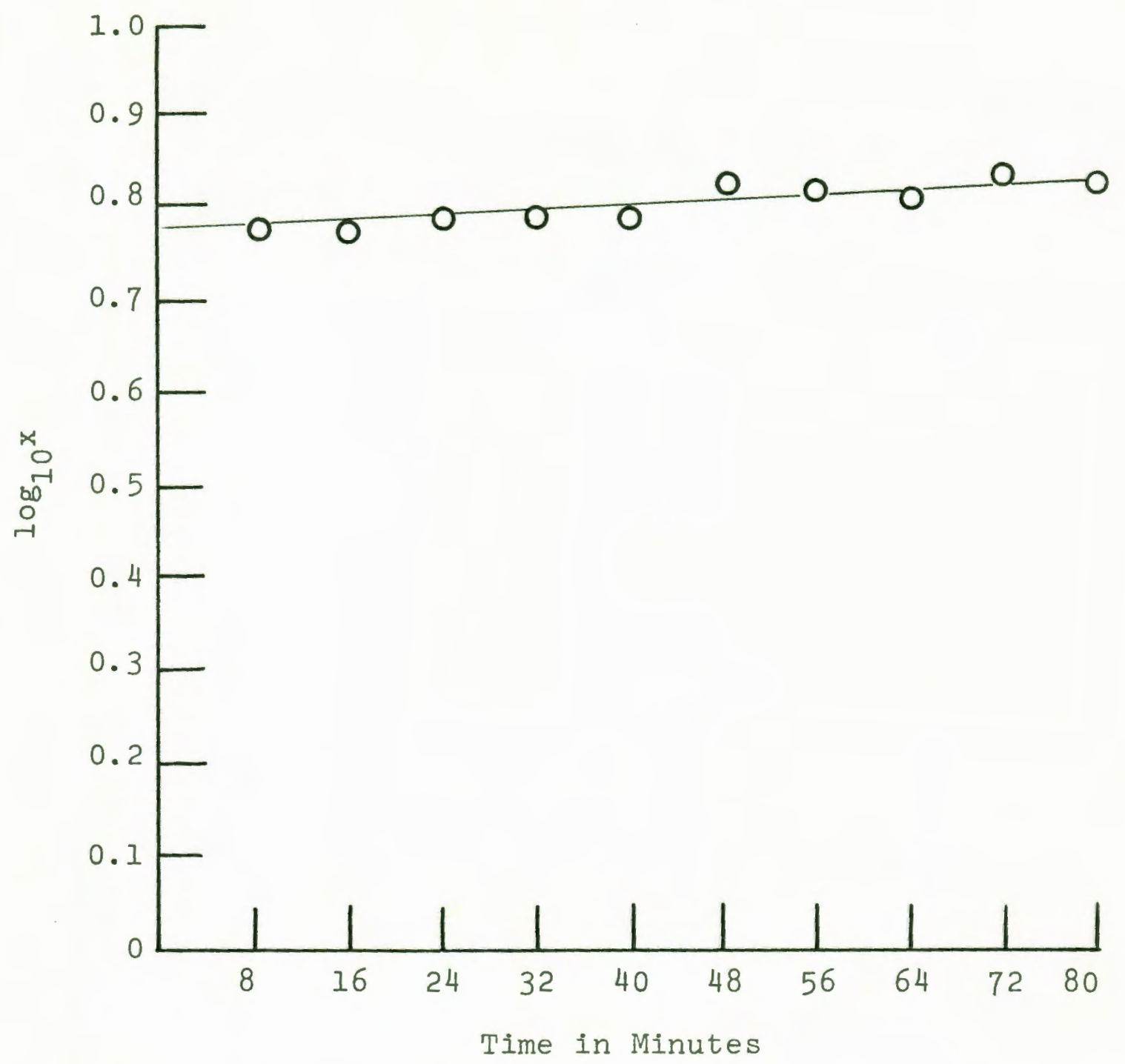

Figure 8. Plot of $\log _{10} x$ versus $t$ as used for the calculation of a sedimentation coefficient for gamma globulin (IgG) isolated from normal rabbit serum. 
determined as follows:

$$
\begin{aligned}
& \frac{d \log x}{d t^{\prime}}=5.99 \times 10^{-4} \\
s & =\frac{2.303}{60 w^{2}}\left(\frac{d \log x}{d t^{3}}\right) \\
& =\left(1.116 \times 10^{-9}\right)\left(5.99 \times 10^{-4}\right) \\
& =6.68 \times 10^{-13} \\
& =6.68 \mathrm{~s}
\end{aligned}
$$

The data indicated taht the purified gamma globulin fraction obtained from normal rabbit serum was IgG, as was the fraction characterized from rabbit antifibroblast antiserum.

Complement Fixation Tests Using IgG Isolated from Rabbit Antifibroblast Antiserum as Antibody and Human Prostatic Fibroblasts as Antigen

Indicator System. Two units of hemolysin contained in $0.5 \mathrm{ml}$ of a 1:500 dilution gave complete hemolysis of sheep red blood cells as used in these assays. Two full units of complement diluted $1: 75$ and contained in a $1 \mathrm{ml}$ volume was the least amount of complement which could be used in the reaction mixture which gave complete lysis of sheep erythrocytes. 
Test System. The complement fixation test with IgG and fibroblasts was carried out by the same procedure as that described for antifibroblast antiserum and fibroblasts using concentrations of constituents of the indicator system as detalled above. Results were recorded in Table VIII.

In the experiment reported in Table VIII, undiluted fibroblast antigen suspension and undiluted IgG purified from rabbit antifibroblast antiserum provided the greatest amount of complement fixation. It was evident that IgG possessed the function of antibody which could react with fibroblast cells to promote cell lysis.

Effects of IgG Obtained from Rabbit Antifibroblast Antiserum and Normal Rabbit Serum on Mixed Human Prostatic Cultures Composed of Fibroblasts and Epithelial Cells

As shown in Figure 9 only IgG isolated from rabbit antifibroblast antiserum had the abllity to destroy fibroblasts, while epithelial cells persisted. IgG from normal rabbit serum like untreated normal rabbit serum did not have any effect on fibroblasts or epithelium. Thus formation of IgG in antifibroblast antiserum must have occurred in specIfic response to the fibroblast antigen.

Effects of Non-Heat Inactivated Rabbit Antifibroblast Ant1serum Absorbed with H. ED. 2 Cells on Human Prostatic Cultures Composed of Fibroblasts and Epithelial Cells Photographs taken before and after treatment as shown 
A COMPLEMENT FIXATION REACTION WITH IgG ISOLATED FROM RABBIT ANTIFIBROBLAST ANTISERUM AND SUSPENSIONS OF HUMAN PROSTATIC FIBROBLASTS SERVING AS TEST SYSTEM REACTANTS

IgG Dilutions

Fibroblast Antigen Dilutions

\begin{tabular}{lrr}
\hline Undiluted & $1: 5$ & $1: 10$ \\
++++ & +++ & ++ \\
$-\infty$ & neg. & neg. \\
& neg. & neg.
\end{tabular}

Symbols :

to to t+t: Degree of complement flxed in the test system neg.: Negative or no complement fixed in test system

Not done at these dilutions because of insufficient amount of f1broblast antigen preparation.

Undiluted fibroblast antigen contained $2.35 \times 10^{6}$ cells per ml. Undiluted IgG antibody contained $0.29 \mathrm{mg}$ protein per $\mathrm{ml}$. 
Figure 9. Observation of lytic effects by purified IgG isolated from rabbit antifibroblast antiserum on fibroblasts derlved from human prostatic explant outgrowth composed of fibroblasts and epithelial cells.

Mixed cultures of fibroblasts and epithelial cells derived from explant outgrowth of human prostatic tissues were photographed (Magnification $\mathrm{x} 160$ ) at zero time before treatment and $23 \mathrm{hr}$ following treatment. In the interim preparations were cultivated in Eagle's medium containing $20 \%$ fetal bovine serum at $37^{\circ}$ in a $95 \%$ a $1 r-5 \% \mathrm{CO}_{2}$ water-saturated environment. Photographs $1 \mathrm{a}$ and $2 \mathrm{a}$ represent both preparations before treatment.

Ib: This culture was allowed to react with complement and IgG 1solated from rabbit antifibroblast antiserum according to routine procedures described in Materials and Methods. The preparation was photographed $23 \mathrm{hr}$ after treatement.

2b: The culture was allowed to react with complement and IgG 1solated from normal rabbit serum, according to procedures described. The preparation was photographed 23 hr after treatment. 

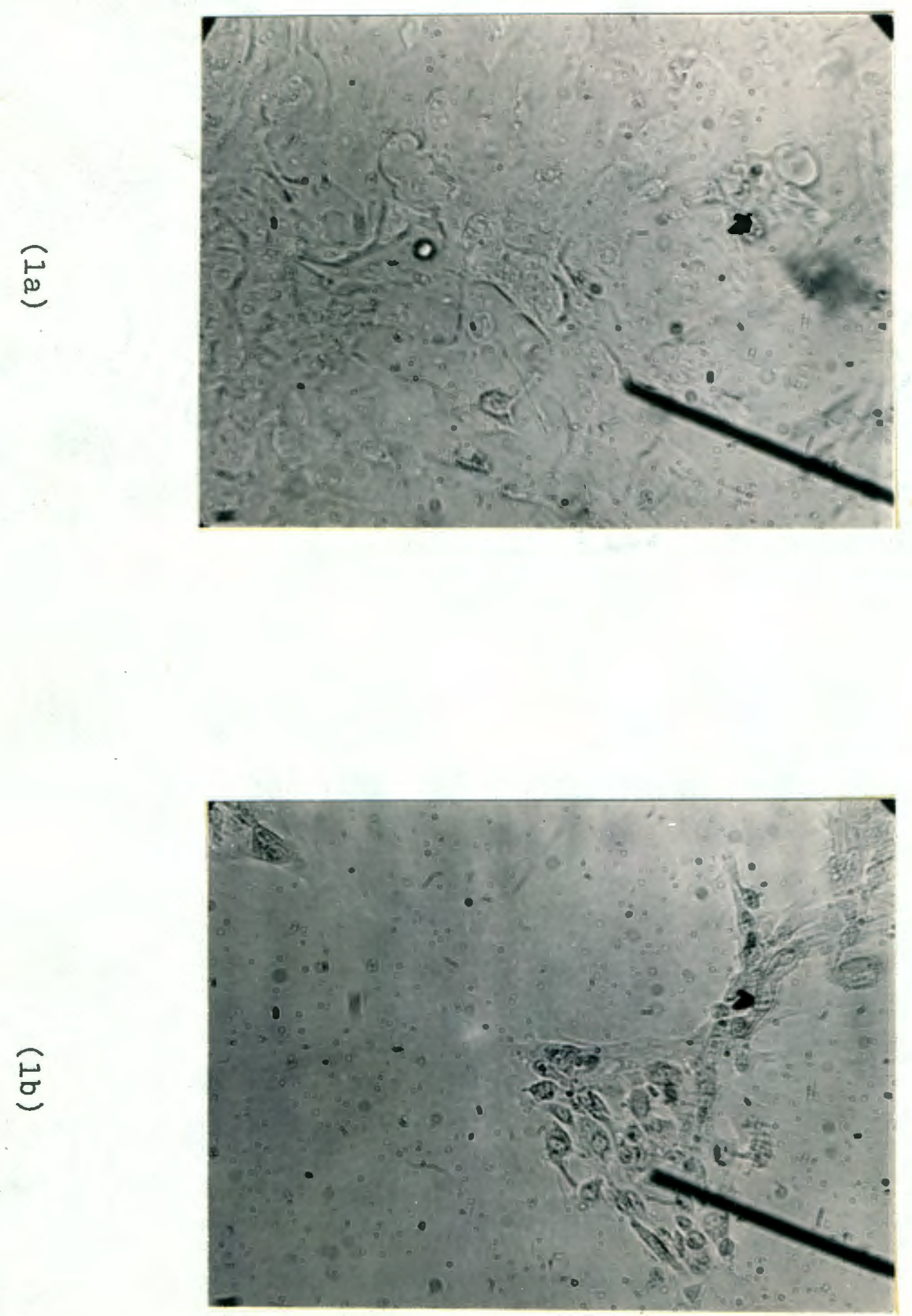

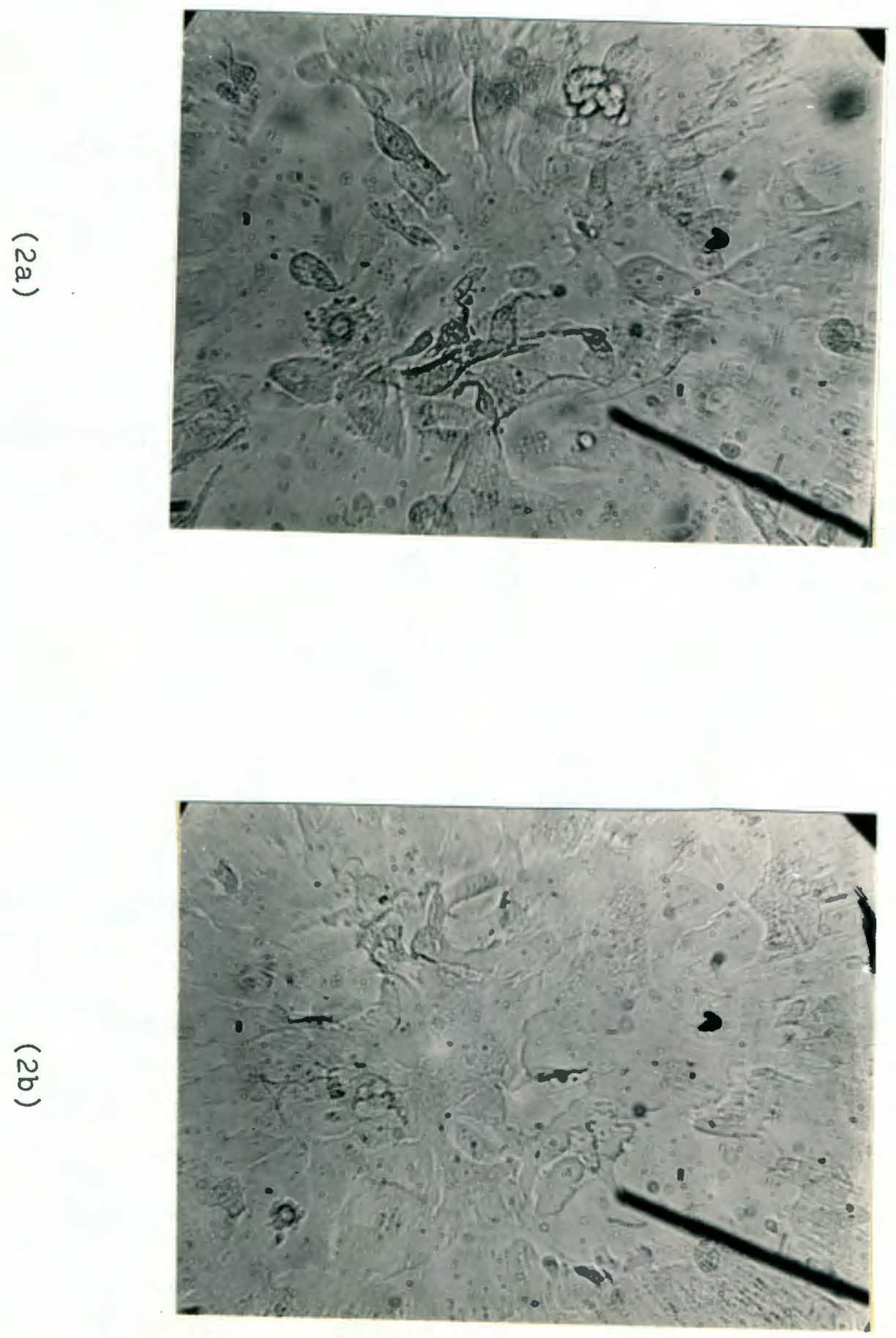
in Figure 10 indicated that rabbit antifibroblast antiserum absorbed earlier with H. Ep. 2 cells (derived from human epidermold carcinoma of the larynx) destroyed cells which resembled flbroblasts morphologically but had no effect on cells displaying characteristics of epithelium. Antiserum appeared to remain speciflc for fibroblasts. It was of considerable interest to speculate as to whether or not there were certain different receptor site components on cell surfaces which accounted for the different antigenic responses of fibroblasts and epithel1al-like-cells. 
F1gure 10. Effect of complement and non-heat-inact1vated, H. Ep. 2-cell absorbed, rabbit antifibroblast ant1serum on cellular outgrowth of mixed cell types obtalned from human prostatic explant tissue.

The preparation was photographed (Magnification $\times 160$ ) before (Ia) and $23 \mathrm{hr}$ after (Ib) treatment with reactants. Cells were cultivated in Eagle's medium containing $20 \%$ fetal bovine serum.

1b: Photograph of culture $23 \mathrm{hr}$ after treatment with complement diluted $1: 5$ and undiluted-H. Ep. 2-cell-absorbed rabblt antifibroblast antiserum. 

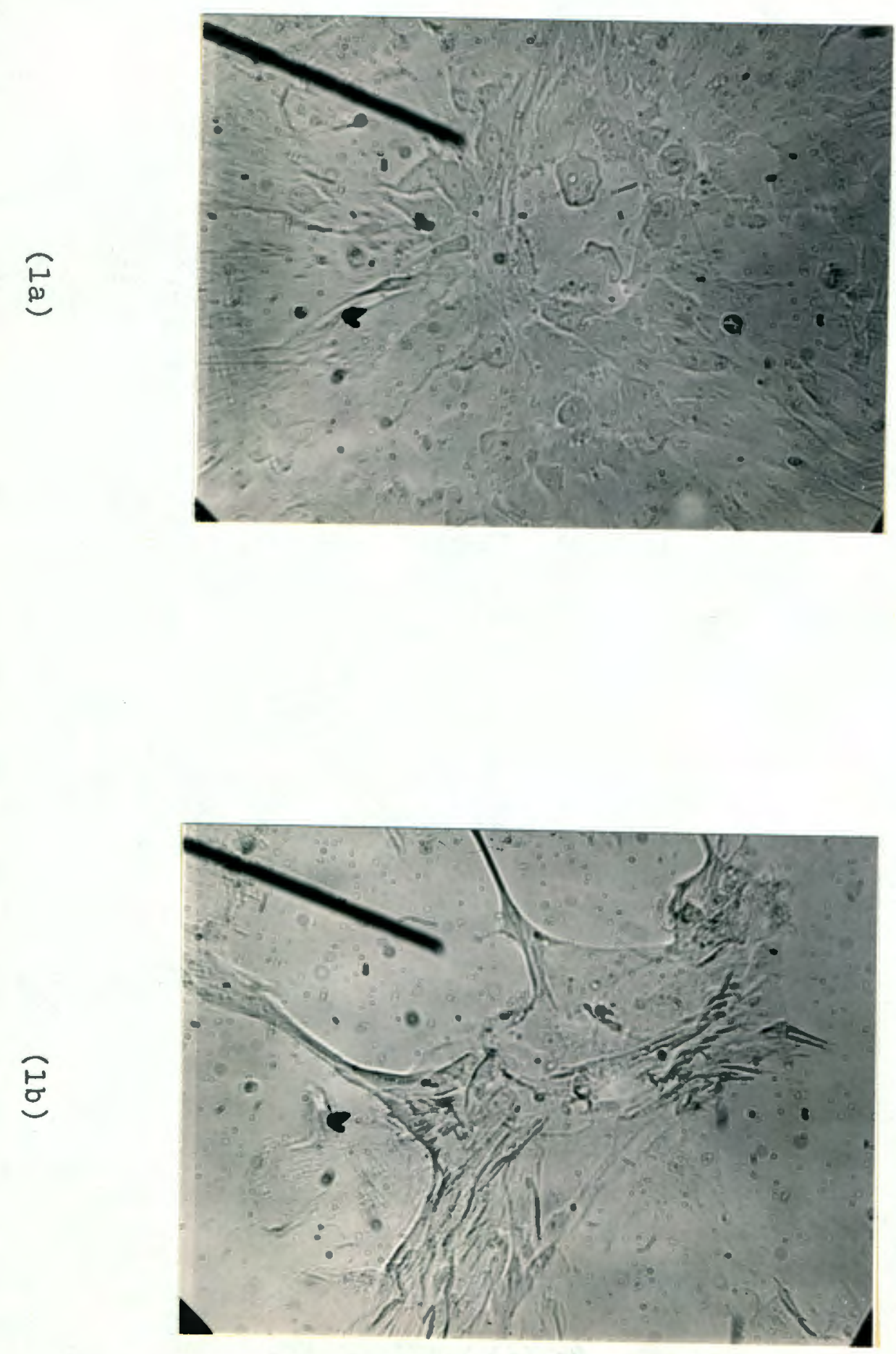


\section{DISCUSSION}

Experimental results presented in this thesis showed that rabbit antifibroblast antiserum in the presence of complement had the capacity to destroy human prostatic cells resembing fibroblasts morphologically, while cells displayIng characteristic eplthellal-like morphology were unaffected. Control systems containing normal rabbit serum supplemented with complement or rabbit antifibroblast antiserum alone had no effect on flbroblasts and ep1thelium derived from prostatic tissues. These data suggested that antifibroblast antiserum was specific for the ifbroblast antigen. The observation that fibroblasts and eplthelial cells might have certain differences in antigenicity was extended further when 1 t was shown that antifibroblast antiserum absorbed in the presence of H. Ep. 2 epithelial-like cells lysed fibroblasts only and not epithelial cells found growing in mixed cell type cultures derived from human prostate tissue. Concentrations of rabbit antifibroblast antiserum diluted $1: 2$ in the presence of complement diluted 1:5 provided the most effective reaction mixture for observing lysis of flbroblasts. When fibroblasts and epithelial cells found in cultures of prostatic explant outgrowth were treated with antibody plus complement, fibroblasts lysed and disappeared, while epithelium remained intact and multiplied.

In general, ammonium sulfate precipitation followed by DEAE cellulose column chromatography were found to be very 
useful methods for isolation of IgG from various serum sources $(20,23)$; these methods were frequently used in enzyme purification studies also (19, 14). IgG isolated from rabbit antifibroblast antiserum caused fibroblast lysis. Concentration studies were not carried out to determine whether purified IgG or crude antifibroblast antiserum was most effective in promoting fibroblast lysis. It was not known if IgG was partially denatured in the purification process. Such questions require further investigation.

According to data reported in this thesis, quantities of IgG purified from rabbit antifibroblast antiserum and normal rabbit serum were very close in value, while sedimentation coefficients varied slightly. Variability must be due to the fact that standard conditions were not maintained when such determinations were made. In regard to IgG activity, perhaps responses obtained with IgG as compared with crude rabbit antifibroblast antiserum differed as a result of partial inactivation of IgG protein during purification processes of gamma globulin. Our findings demonstrated the usefulness of the complement fixation test in observing lysis of fibroblasts when subjected to antifibroblast antiserum. The test was shown to be rapid and specific. The mechanism of complement fixation has to do with the fact that an antibody-complement complex binds to surface receptors of antigens (11) after which the reaction, such as lysis, occurs. Complement binding sites are located on heavy chains of 
antibody molecules found just before and after the s-s

regions of antibody. It is known that IgG combines with complement in this way also. Thus fibroblasts are lyzed and disappear after treatment of cells with antifibroblast antiserum and complement while epithelial cells are maintalned and continue to proliferate in pure culture. This procedure allows investigators working in the fleld of cancer carcinogenesis to use such epithelial cultures as model systems in order to study initial events of the malignant conversion process. 
Antifibroblast antiserum was prepared in rabbits by Immunizing 6 animals with human prostatic fibroblasts cultivated and transferred through 14 passages in tissue culture. By routin complement fixation procedures complement was fixed by antifibroblast antiserum complexed with suspensions of fibroblast cells. Likewise, when rabbit antifibroblast antiserum and complement were added to cultures of mixed cell types obtained from cellular outgrowth of prostatic explant tissues, fibroblasts were destroyed but eptthelial cells remained intact in culture and continued to multiply. Normal. rabbit serum used for controls had no effect on tissue cultures.

Ammonium sulfate precipitation followed by DEAE cellulose column chromatography was adopted to purify IgG from rabbit antifibroblast antiserum and normal rabbit serum. IgG obtained from rabbit antifibroblast antiserum and supplemented with complement eliminated growth of fibroblasts but not epithelium. IgG obtained from normal rabbit serum and tested in the presence of complement had no effect on cultures of prostatic fibroblasts and epithelial cells.

Following rabbit antifibroblast antiserum absorption with H. Ep. 2 cells, absorbed antiserum in the presence of complement retained the capacity to lyse fibroblasts but not epithelial cells.

Thus fibroblasts were destroyed and after treatment with rabbit antifibroblast antiserum and complement, 
epithelial cells persisted intact and multiplied in pure culture. As a result of these research efforts a model system was provided so that other investigators could study inftial events in the conversion of normal prostatic epithelium to malignant cells. 


\section{BIBLIOGRAPHY}

1. Burrel1, Robert. 1974. Experimental Immunology, 4 th ed. Burgess Publishing Company. p. 44-47.

2. Campbel1, Dan. H., Fustine S. Garvey, Natalie E. Cremer, and Dieter H. Sussdorf. 1970. Methods in Immunology, and ed. W. A. Benjamin, Inc., New York. p. 76-79, 45-48, 189-191, 193-197, 104-110.

3. Chervenka, C. H. 1969. A Manual of Methods for the Analytical Ultracentrifuge. Spinco Division of Beckman Instruments Inc., Palo Alto, California. p. 26-29.

4. Cho-Chung, Yoon Sang, and Pietro M. Gullino. 1973. Mammary Tumor Regression. J. B10I. Chem. 248(13): 4743-4749.

5. Cohen, Max H., Allan D. Bernstein, and Paul H. Levine. 1974. Hematological and Serological Effects of Rauscher Leukemia Virus and Epstine-Barr Virus on Immunosuppressed Newborn Submhuman Primates. Oncology. 29:353-363.

6. Ennis, Francis. 1973. Host Defense Mechanisms against Herpes Simplex Virus. I. Control of Infection in vitro by Sensitized Spleen Cells and Antibody. Infect. Immunity. 7(6):898-904.

7. Epstin, M. A., and B. G. Achong. 1968. Specific Immunofluorescence Test for the Herpes-Type EB Virus of Burkitt Iymphoblasts, Authenticated by Electron Microscopy. J. Nat. Cancer Inst. 40:593-607.

8. Froehlich, Jeffrey E., and Tassos P. Anastassiades. 1974. Role of $\mathrm{pH}$ in Fibroblast Proliferation. J. Ce11. Physiol. $84(2): 253-260$.

9. Garfinkle, B., and B. R. McAuslan. 1974. Transformation of Cultured Mammalian Celis by Viable Herpes Simplex Virus Subtypes 1 and 2. Proc. Nat. Acad. Sc1. 71(1):220-224.

10. Hickmar, Scot, Larry J. Shapiro, and EIizabeth F. Neufeld. 1974. A Recognition Marker Required for Uptake of a Lysosomal Enzyme by CuItured Fibroblasts. Biochem. Biophys. Res. Comm. $57(1): 55-61$. 
11. Irie, Kenj1, Reiko F. Irie, and Donald L. Morton. 1974. Evidence for in vivo Reaction of Antibody and Complement to Surface Antigens of Human Cancer Ce11s. Science. 186:454-456.

12. Kim, Kwang Soo, and Richard I. Carp. 1973. Effect of Proteolytic Enzymes on the Infectivity of a Number of Herpesviruses. J. Infect. Dis. 128(6): $788-790$.

13. Leslie, R. G. Q., and S. Coher. 1974. Cytophilic Activity of IgG2 from Sera of Unimmunized Guineaplgs. Immunology. $27: 577-587$.

14. Iin, Marie C. M., and Conrad Wagner. 1975. Purification and Characterization of $\mathrm{N}$-Methyalanine Dehydrogenase. J. B10I. Chem. 250(10):3746-3751.

15. Litwin, J. 1974. Growth of Human Diploid Fibroblasts in Media with Different Amino Acid Composition. J. Cel1 Sci. 14:671-680.

16. Maroudas, N. G. 1973. Chemical and Mechanical Requirements for Fibroblast Adhesion. Nature. $224: 353-354$.

17. N1ewiarowsk1, Stefan, Erwin Regoecz1, and J. Fraser Mustard. 1972. Adhesion of Flbroblasts to Polymerizing Fibrin and Retraction of Fibrin Induced by F1broblasts. Proc. Soc. Exp. B101. Med. 140: 199-204.

18. Rosenberg, Gary L., and Abner Louls Notkins. 1974. Induction of Cellular Immunity to Herpes Simplex Virus: Relationship to the Humoral Immune Response. J. Immunol. 112(3):1019-1025.

19. Schwartz, Lawrence B., and Robert G. Roeder. 1975. Purification and Subunit Structure of Deoxyribonucleic Acid-dependent Ribonucleic Acid Polymerase II. from the Mouse Plasmacytoma, MOPC 315. J. B101. Chem. 250(9):3221-3228.

20. Seon, B. K., and D. Pressman. 1975. Isolation and Characterization of a $\mathrm{C}_{\mathrm{H}} 2$ Domain Fragment of Human IgG. Immunochemistry. 121:333-337.

21. Tomkins, Graeme A., Eric J. Stanbridge, and Leonard Hayflick. 1974. Viral Probes of Aging in the Human Diploid Cell Strain WI-38. Proc. Soc. Exp. B101. Med. 146:385-390. 
22. Verjans, H. L., B. A. Cooke, F. H. De Jong, C. M. M. De Jong, and H. J. Van Der Molen. 1973. Evaluation of a Radiolmmunoassay for Testosterone Estimation. J. Steroid Biochem. 4:665-676.

23. Vidal, Glorietta P., Taifi Kato, and Makoto Sasaki. 1975. Cleavage Sites of Human IgG by Soluble and Water-Insoluble Stem Bromela1n. Immunochemistry. 12: 403-409.

24. Wallis, Craig, and Joseph L. Helnick. 1971. Herpesvirus Neutralization: The Role of Complement. J. Immunol. 107(5):1235-1242.

25. Wilson, Jean D. 1975. Dihydrotestosterone Formation in Cultured Human Fibroblasts. J. Biol. Chem. $250: 3498-3504$.

26. Yamada, Kenneth M., and James A. Weston. 1974. Isolation of a Major Cell Surface Glycoprotein from Fibroblasts. Proc. Nat. Acad. Sci. 71(9): 3492-3496.

27. Yamanaka, N., and D. Deamer. 1974. Superoxide Dismutase Activity in WI-38 CeII Cultures: Effects of Age, Trypsinization and Sv-40 Transformation. Physiol. Chem. Physics. $6: 95-106$. 